\title{
FEMALE INSTITUTIONAL DIRECTORS ON BOARDS AND FIRM VALUE
}

\author{
María Consuelo Pucheta-Martínez \\ Assistant Professor \\ University Jaume I \\ Department of Finance and Accounting \\ Campus del Riu Sec, S/n \\ 46012-Castellón- \\ Spain \\ e-mail:pucheta@uji.es \\ Inmaculada Bel-Oms \\ $\mathrm{PhD}$ \\ University Jaume I \\ Department of Business Administration and Marketing \\ Campus del Riu Sec, S/n \\ 46012-Castellón- \\ Spain \\ e-mail: ibel@uji.es \\ Gustau Olcina-Sempere \\ Assistant Lecturer \\ University Jaume I \\ Department of Education \\ Campus del Riu Sec, S/n \\ 12071-Castellón- \\ Spain \\ e-mail: golcina@uji.es
}




\title{
FEMALE INSTITUTIONAL DIRECTORS ON BOARDS AND FIRM VALUE
}

\begin{abstract}
The aim of this research is to examine what impact female institutional directors on boards have on corporate performance. Previous research shows that institutional female directors cannot be considered as a homogeneous group since they represent investors who may or may not maintain business relations with the companies on whose corporate boards they sit. Thus, it is not only the effect of female institutional directors as a whole on firm value that has been analysed, but also the impact of pressure-resistant female directors, who represent institutional investors (investment, pension and mutual funds) that only invest in the company, and do not maintain a business relation with the firm. We hypothesise that there is a non-linear association, specifically quadratic, between institutional and pressure-resistant female directors on boards and corporate performance. Our results report that female institutional directors on boards enhance corporate performance, but when they reach a certain threshold on boards $(11.72 \%)$, firm value decreases. In line with female institutional directors, pressure-resistant female directors on boards also increase firm value, but only up to a certain figure (12.71\% on boards), above which they have a negative impact on firm performance. These findings are consistent with an inverted-U shape relationship between female institutional directors and pressure-resistant female directors and firm performance.
\end{abstract}

Keywords: Corporate governance, female institutional directors, pressure-resistant female directors, board of directors, firm value 


\section{INTRODUCTION}

Recent research (Ferreira and Matos, 2008; Elyasiani and Jia, 2010; Ruiz-Mallorquí and Santana-Martín, 2011; Pucheta-Martínez and García-Meca, 2014) has paid growing attention to the role that institutional investors play as a mechanism of corporate governance.

The influence of institutional investors on leverage (Booth and Deli, 1999), financial reporting quality (Pucheta-Martínez and García-Meca, 2014), earnings management (García-Osma and Gill de Albornoz-Noguer, 2007) and dividend policy (Han et al., 1999; Short et al., 2002; Farinha, 2003; Abdelsalam et al., 2008; Hovakimian and Li, 2010), among others, has been reported in prior research. Most of these investigations focus on the role of institutional investors as shareholders; however, previous evidence has paid scarce attention to the role of institutional investors as directors. Furthermore, the academic literature on institutional investors and firm value has also paid little attention to aspects such as gender diversity on corporate boards.

The literature about corporate governance demonstrates that gender diversity on corporate boards may influence the supervision and control of the board's activities (see, e.g., Adams and Ferreira, 2009; Francoeur et al., 2008; Huse et al., 2009; Huse and Solberg, 2006; Nielsen and Huse, 2010; Schwartz-Ziv, 2011). If we focus on the particular role of institutional female directors on corporate boards, research shows that they have an impact on firm risk (Johnsen and McMahon, 2005; Welch and Wang, 2013), earnings quality (Johnson and Greening, 1999) and investment opportunities (Johnsen and McMahon, 2005; Loukil and Yousfi, 2013). Thus, given the importance of women directors on boards in allocating capital to corporations, their contribution to firm governance (Campbell and Mínguez-Vera, 2008; Terjesen et al., 2009), the role played by institutional directors on corporate boards and the scant research performed combining female institutional directors and firm value (Atkinson et al., 2003; Garba and Abubakar, 2014; Welch and Wang, 2013), an understanding of how female institutional directors sitting on boards of directors affect firm value is undoubtedly needed. Therefore, we aim to contribute to the growing literature on the role of women, particularly female institutional directors, in corporate governance. Our study tries to fill this gap in the literature as, to the best of our knowledge, we are the first to study the influence of female directors appointed by institutional investors on firm value. 
Hence, the purpose of this study is twofold. Firstly, we aim to examine the effect of female institutional directors on boards on firm value. Secondly, we distinguish between pressure-sensitive female directors, who represent institutional investors that maintain business relations with the company where they hold a directorship, and pressure-resistant female directors, whose business activity is not related to the company in which they hold a directorship. Unfortunately, the category of pressure-sensitive female institutional directors has been dropped from the analysis, because in Spanish boards of listed firms pressure-sensitive institutional directors are overwhelmingly represented by men, and consequently, the proportion of pressure-sensitive female directors provided by our sample is insufficient. Accordingly, we only focus on the repercussions of pressure-resistant female institutional directors on corporate performance.

Our research contributes to the literature in several ways. First, we show that female institutional directors as a whole influence corporate performance, and when we analyse the particular role played by pressure-resistant female institutional directors, the evidence demonstrates that they also have an effect on firm value. These findings support the thesis that pressure-resistant female institutional directors behave in line with female institutional directors and, consequently, both groups are involved in corporate governance in the same way. Therefore, this evidence shows that female institutional directors and pressure-resistant female directors perform the same role concerning firm value. A lot of research about institutional ownership has been performed; however, it has, to date, failed to reach a consensus on whether institutional investors, particularly women, carry out a specific role in corporate boards. Second, our results suggest that the supervision (contest or monitoring) hypothesis prevails until the proportion of female institutional directors and pressure-resistant female directors on boards reaches the inflection points of $11.72 \%$ and $12.71 \%$, respectively, but beyond these turning points, the expropriation (collusion or entrenchment) hypothesis prevails. The combination of these two hypotheses leads to the prediction of a nonlinear relationship, specifically quadratic (an inverted U), between female institutional female directors and pressure-resistant female institutional directors and firm performance. Thus, this evidence supports the view of the active and effective monitoring role of managers played by female institutional directors and pressure-resistant female directors; but when their presence reaches the inflection points, then, female institutional directors and 
pressure-resistant female directors are less likely to actively monitor managers of the companies on whose boards they sit, due to conflicts of interest from existing or future business relations with the firm, because of their relatively short-sighted goals, or because they do not have the capability, playing a passive and ineffective monitoring role. Third, we demonstrate an association between boards of directors and firms' financial strategy. Firm value is a financial mechanism of the managerial discipline, and accordingly, female institutional directors and pressure-resistant female directors can improve managerial monitoring in a substitute/complementary way, as long as their presence on boards does not reach a certain turning point. Further, in line with the board of directors literature, which suggests that resource dependence theory is more often supported than other board perspectives (e.g. Christopher, 2010; De Villiers et al., 2011; Hillman et al., 2009; Johnson et al., 1996; Sing, 2007), including agency theory, our findings support the extensive literature that stresses the strategic consultant role of board members, rather than (or in addition to) exercising independent control. Fourth, we extend previous research, mainly focused on the Anglo-Saxon context, to a bank-oriented system with lower legal investors' protection. Therefore, this paper also analyses the role of financial institutions when they are not only creditors, but also hold a directorship on the board and even when they hold a significant ownership. Finally, our study, as far as we know, is the first to explore in the Spanish context the relationship between female institutional directors and pressure-resistant female institutional directors on boards and firm value. Such a relationship is more difficult to capture in a US or UK setting, where it is less common for directors to be appointed by institutional investors. Thus, we argue that the Spanish context provides an opportunity to examine the effect of female institutional directors on firm value.

The article is organised as follows. In the next section, we describe the institutional setting and in section three we review the main theoretical ideas and provide the hypotheses. Section four describes the empirical design, section five contains the results and finally, in section six, we summarise and conclude. 


\section{INSTITUTIONAL SETTING}

Unlike the Anglo-Saxon system, the Spanish corporate governance system is characterized by the presence of a high ownership concentration, a lack of liquid capital markets and no active market control. These features mean that the board of directors becomes the prevalent mechanism of control and the presence as directors of the large block-holders is known as institutional directors. These directors play a significant role because they have an important position on boards, representing the interests of large shareholders and institutional investors (Kirchmaier and Grant, 2005).

In the civil law environment, most European countries, where investor protection law is weak and the principal agency problem is based on the expropriation of minority shareholders' wealth by large shareholders (Boubakri and Ghouma, 2010; Nekhili and Gatfaoui, 2013; Giner and Pardo, 2015), institutional investors become the most important controlling shareholders and participate actively as directors on the board of directors. According to the survey by Heidrick and Struggles (2011), directors appointed by institutional investors account for $40 \%$ of the directorship in Spain, $35 \%$ in Belgium and $22 \%$ in France, while they only account for $2 \%$ of British firms' directorships. Meanwhile, in common law countries independent directors play the most important role in corporate governance (Masulis and Mobbs, 2011). Thus, Spain is the European country with the highest presence of institutional investors on the boards of large firms (De Miguel et al., 2004), in contrast to the Anglo-American context, where it is less common for institutional investors to appoint directors to the board. This high proportion of institutional directors gives an idea of stability, so that these directors have full opportunities to engage in strategic financial decisions (Elyasiani and Jia, 2010). Additionally, Spain has a financial system oriented to banks and, contrary to their Anglo-Saxon counterparts, Spanish financial institutions have, by tradition, played an important role in the governance of non-financial firms. Banks face growing pressure from the financial markets and have widened their traditional lending and borrowing activities to others like asset management and underwriting share issues. This role has even been expanded in recent years due to the deregulation process.

In this context, Spain has performed significant legal and institutional changes in order to enhance the transparency of the stock markets, to protect minority shareholders and to increase firm 
value. The regulatory bodies have published a set of codes of Corporate Governance: the Olivencia Report in 1998, Aldama Report in 2003, and finally, the Unified Code of Corporate Governance or Conthe Code in 2006, modified in 2015, all of which are characterized by recommending compliance with corporate governance regulations, and in the case of non-compliance, requiring companies to explain the reasons. Regarding the board composition, the Conthe Code (2006) distinguishes three types of directors: independent, executive and institutional directors. Institutional directors are nonexecutive directors representing reference shareholders, most often banking and insurance companies or investment funds. These codes have also helped to regulate the presence of women in decisionmaking bodies.

The repercussions of gender diversity on corporate boards (within the corporate governance system) have become relevant today for shareholders and managers of modern firms, mass media, politicians and legislators, among others, because many countries have already legislated laws or advanced policies that are aimed at increasing the percentage of women directors on boards of directors (e.g. Norway, Spain and France). The drive to promote women's presence in the Spanish labour market, in general, and boards of directors, in particular, came from the socialist Prime Minister José Luís Rodríguez Zapatero, who made gender equality one of his government's top priorities, and approved the Conthe Code (2006) and the Act 3/2007 of 22 March 2007, for Effective Equality between Women and Men (LOIMH). The Conthe Code (2006) recommended a female presence on decision-making bodies, but it was the LOIMH (2007) that framed the regulation of the appointment of men and women on boards of directors in an equitable way. In fact, the LOIMH (2007) recommended Spanish boards of listed companies to reach a gender quota of $40 \%$ by 2015 . In the same vein, the Conthe Code (2006), updated in 2015, recommends a gender quota of $30 \%$ on boards of listed firms to be achieved by 2020. According to Heidrick and Struggles (2014), in Spain the gender quota on boards of directors has increased during the last eight years, reaching a quota of $13 \%$ in 2013. Although the tendency is to increase the representation of female directors on boards, it seems that the LOIMH (2007) has not been as successful as expected, given the figure reached. Furthermore, it is possible that this increase is due not only to the LOIMH (2007), but also to a tendency towards the presence of women directors on boards. Gómez-Ansón (2005) and Mateos et al. (2010) emphasise that 
the majority of women directors making up the boards of directors of Spanish listed firms are institutional directors. This argument is supported by the figures of the descriptive statistics calculated with our database, which also show that within the category of female institutional directors, the majority are pressure-resistant female directors, while the presence of pressure-sensitive female directors is limited. This is consistent with prior research conducted in Spain (López-Iturriaga et al., 2015; Manzaneque et al., 2016) reporting that the proportion of pressure-resistant directors on boards is higher than pressure-sensitive directors.

\section{THEORETICAL BACKGROUND AND HYPOTHESES DEVELOPMENT}

This paper draws on agency theory to examine the relationship between female institutional directors and firm value. This is the theory most used by investigators to analyse the relationship between board characteristics and firm value. According to this theory, the separation between the principal (shareholders and other stakeholders such as users of financial information or blockholders) and the agent (directors and managers) of the firm generate information asymmetries and incomplete contracts between the parties, because the owners of a firm have delegated to managers to act on their behalf, generating agency problems (Jensen and Meckling, 1976). Internal mechanisms of corporate governance, such as boards of directors, may reduce agency costs and become an important mechanism to increase firm value.

In this vein, board composition is a key mechanism to mitigate or eliminate agency costs in companies and align the interests of principals and agents, focusing on the control as the most important function of the board of directors. Outside directors will act independently from their inside director counterparts and will act as good monitors for shareholders' interest. Given that managers are often driven by their own self-interest, large shareholders such as institutional investors have a strong incentive to monitor and motivate managers to maximize firm value instead of pursuing managerial objectives (Allen et al., 2001; Jensen, 1986; Shleifer and Vishny, 1986). Furthermore, agency theory also posits that females on corporate boards might strengthen existing control mechanisms over managers and executives, since board gender diversity increases board independence because women ask more questions than men (Carter et al., 2010). In this vein, previous research provides evidence 
that board gender diversity has an important effect on fostering good corporate practice (Burgess and Tharenou, 2002; Rogelberg and Rumery, 1996), dividend policy (Van Pelt, 2013; Wellalage et al., 2012) and financial reporting quality (Gulzar and Wang, 2011; Qi and Tian, 2012), among others. Accordingly, gender diversity on corporate boards may act as a mechanism to control and monitor managers (Adams and Ferreira, 2009; Carter et al., 2003), which may mitigate agency costs (Hillman and Daziel, 2003) and, consequently, increase firm value. Therefore, the combination of institutional directors and gender diversity on corporate boards may result in an enhancement of firm value. It seems that female directors provide an incentive for change towards board decisions, particularly firm performance, and therefore, in line with Ahl (2006), within current research on gender theory, it needs to be better reflected. In this sense, the paper by Ahl (2006) provides a critical view of the way research on gender is conducted, since most previous papers on female entrepreneurship focus mainly on recreating the subordinate role of women in comparison to men, but they fail to stress explicitly the essential differences between males and females, with a reliance on stereotypical expectations of gender roles

Thus, building on sociology, cognitive and psychology literature, and focusing on gender diversity on corporate boards, authors such as Bilimoria (2000) and Fondas and Sassalos (2000) argue that the presence of women in the boardroom leads to more civilized ${ }^{2}$ behaviour and sensitivity to other perspectives ${ }^{1}$. Jianakopolos and Bernasek (1998) and Byrnes et al. (1999) suggest that women tend to prefer a lower level of risk than men'. In the same vein, female directors may exercise greater control over management and may be quicker to detect opportunistic behaviours than male counterparts $^{1}$ (Khazanchi, 1995; Ruegger and King, 1992). All these qualities of women's behaviour may align the interests of all shareholders and, as a result, firm value may increase. According to Erhardt et al. (2003), diversity in a decision-making group enhances performance by increasing the decision-making capacity. This opinion is supported by Maznevski (1994), who argues that diversity has the potential to benefit group decision-making, which may improve performance by enhancing integration and communication. Simons and Pelled (1999) showed that cognitive diversity was associated with positive effects on organizational performance. However, Dong (2014) reports that women investors may be less sophisticated and sensitive financially than male investors ${ }^{1}$ and, 
therefore, they would impact negatively on firm value. Thus, based on cognitive, psychological and sociological approaches, women on corporate boards may have a positive or negative influence on corporate performance.

To the best of our knowledge, only a small number of papers (Barber and Odean, 2001; Dong, 2014; Talpsepp, 2013) analyse this association. While Barber and Odean (2001) and Talpsepp (2013) show that female institutional directors on boards were positively associated with firm value, since heterogeneous boards produced more opinions and critical questions that could influence firms' performance (Burke, 1997; Robinson and Dechant, 1997), Dong (2014) suggests that institutional women investors are associated with worse predicted performance. Thus, this analysis tries to fill this gap in the previous literature.

The central role of institutional directors on boards, who represent institutional investors considered shareholders of reference, has been to maximize the benefits of their owners. This perception has led some institutional investors to give up their traditional passive role and become actively engaged in management activities directly through their shareholding, and indirectly by trading their stocks. According to Gillan and Stark (2003), the activism of institutional investors as a control mechanism has been enhanced in the last few years, which is suggested by the theory and confirmed by the empirical evidence (Almazán et al., 2005). This view is supported by authors such as Huson (1997), Carleton et al. (1998) and Karpoff (1999), among others, who argue that active influential investors become a corporate governance mechanism since they can monitor management and improve performance (Huson, 1997; Carleton et al., 1998; Del Guercio and Hawkins, 1999), and finally, increase shareholder value (Almazán et al., 2005). Furthermore, Faccio and Lang (2002) and Ruiz-Mallorquí and Santana-Martín (2011) show that institutional investors play an important role in the corporate decision-making process. However, authors such as La Porta et al. (1999), Levine (1999), Levine et al. (2000) and Jara-Bertín et al. (2012) suggest that the influence of institutional directors on firm value depends on whether the country complies with the civil or common law. It seems that they have much more influence in civil than common law countries. In this regard, GarcíaOsma and Gill de Albornoz-Noguer (2007) show that the monitoring role in European boards within 
the civil law context is played by institutional directors representing controlling shareholders, and not by independent directors.

In recent years, institutional investors on boards have been actively involved in the corporate governance problems of companies where they invest (Jacobson and Aaker, 1993; Rajgopal and Venkatachalam, 1997; Wang, 2014), and have monitored dominant shareholders to avoid a possible fraudulent use of corporate resources and the extraction of private benefits (Chung et al., 2002). Consequently, this argument exposes a positive relationship between institutional ownership and corporate performance (Del Guercio and Hawkins, 1999), since they play a complementary role in governance mechanisms. In the same vein, previous research also finds that institutional directors have an important influence on firm value (Kumar and Singh, 2012; Pound, 1988; Chen et al., 2003; Sacramento et al., 2013). Furthermore, Pound (1988), Sahut and Othmani-Gharbi (2010), Aggarwal et al. (2011) and Lee and Zhang (2011) provide evidence that institutional investors are effective in monitoring management behaviour and improving firm value. Contrary to these findings, authors such as Chen et al. (2003), Wei et al. (2005) and Sacramento et al. (2013), among others, show that institutional investors have a negative influence on firm value, owing to the fact that institutional investors may cooperate with managers, and enjoy private benefits of control or preserve their business relations with their firms and, as a consequence, they are less motivated to monitor their governance. Morck et al. (1988), Yeh (2005) and $\mathrm{Hu}$ and Izumida (2008) find a non-linear relationship, specifically quadratic, between both managerial ownership and ownership concentration and firm value as a combined result of the alignment and entrenchment hypotheses. This logic is extended to institutional ownership by Navissi and Naiker (2006), who show a non-linear association between institutional shareholding and firm value, suggesting that active institutional investors exert a quadratic influence on corporate performance. Thus, the alignment effect should result in a positive association between institutional directors and firm value; however, if institutional directors reach a certain threshold on the board, they may, therefore, entrench themselves and may achieve absolute control of companies and extract private benefits, which may have a negative effect on firm value. In line with this idea, Chirinko et al. (1999) and Zou (2010) report an inverted U-shape relationship between institutional directors on boards and firm value. 
This idea is consistent with the theory of optimal distinctiveness proposed by Brewer (1991), which argues that the effects of group composition are likely to be non-linear: very low and very high proportions of demographic characteristics (gender) are associated with more negative outcomes, whereas balanced proportions lead to positive outcomes (an inverted U-shape). Social identity theory also supports this view (Tajfel, 1978). These theoretical perspectives suggest that within the board there is an intergroup dynamic, which assesses what consequences the heterogeneous relationships have on the process and group performance. These effects refer to cooperation, alliances, cohesion, alignment of interests, agreement, conflicts, non-union, confrontation, polarization or problems sharing relevant information, among others. However, the impact of female directors on outcomes depends on their presence on boards (for more detail, see Ali et al., 2014). In this sense, Knouse and Dansby (1999) show that gender diversity will have a positive effect on firm performance when its presence on boards increases from low to moderate levels. But, as the proportion of female directors increases from moderate to higher levels, they will impact negatively on corporate value, since gender diversity is a demographic attribute that individuals use in order to categorise themselves and others into social groups: in-group (board directors with the same demographic group) and out-group members (board directors from different demographic groups). According to social identity and psychological approaches, board directors who are in-group members may perceive themselves as superior to out-group members and, as a result, their attitude toward them will be adverse. Consequently, male directors on a heterogeneous board (male and female directors) may behave in an unsupportive way, enhancing intergroup conflict or reducing intergroup cooperation, cohesion and communication (Pelled, 1996; Kravitz, 2003). All these negative behaviours cause unproductive intergroup interactions, negatively affecting board effectiveness, which will lead to a decrease in firm performance. Thus, as more females are appointed as directors, their concentration of power with males will presumably become increasingly noticeable and could possibly generate dissatisfaction with those not holding this power, namely, the increasing numbers of females in the organization. Thus, this dissatisfaction may result in individual outcomes such as turnover or lowered productivity, whose collective effect would be detrimental to organizational performance. When power has to be shared among increasingly few members, the restriction to the possible users of this power may lead to 
lost opportunities to use this power for the good of the company, thus affecting firm value. These arguments support a curvilinear association, specifically an inverted $U$ shape, between institutional directors and corporate value.

A curvilinear relationship, inverted or non-inverted $U$ shape, suggests that there is an inflection point that will modify the correlation of internal forces of the board, affecting the intergroup cohesion, the intergroup conflict or the ability of board members to have an influence (Ali et al., 2014). Some authors (Navissi and Naiker, 2006; Al Farooque et al., 2007) examine where the inflection point is in a non-linear relationship between institutional investors and firm performance; however, this issue is still subject to debate. Al Farooque et al. (2007) reported that the turning points in the U-shaped nonlinear relationship between institutional shareholding and firm performance were $29.83 \%$ and $13.16 \%$ when Tobin's Q and ROA, respectively, were used as firm value measures. Specifically, they found that when the proportion of institutional ownership is lower than $29.83 \%$ and $13.16 \%$ for Tobin's Q and ROA, respectively, corporate performance decreases, but when this proportion is higher than these thresholds, the firm value then starts to increase. Furthermore, Lin (2010) showed that institutional ownership started to enhance firm performance when institutional ownership was higher than $81.20 \%$. When institutional ownership was lower than $81.20 \%$, the findings failed to find a significant association between institutional investors and corporate value. Both findings suggest that the monitoring role of institutional investors improves the firm value when their ownership stake in the company reaches a substantial percentage. Thus, only when institutional ownership reaches a considerable proportion do institutional investors start to monitor the company or appear to actively monitor managerial behaviour. Additionally, Navissi and Naiker (2006) found evidence that the inflection point in the nonlinear relationship between institutional investors and firm performance was $30 \%$. As the percentage of institutional directors increased up to this threshold, corporate value increased, but beyond 30\%, firm performance decreased. Frink et al. (2003) demonstrated an inverted U-shaped relationship between companies' gender diversity and firm performance, highlighting that the inflection point may occur somewhere near the midpoint, or equal percentages of men and women. Thus, this evidence suggests that there is an optimal proportion of directors on boards, but the inclusion of additional directors on a board beyond this optimal percentage 
has a negative effect on firm performance. In this sense, the above studies show that the optimal proportions or inflection points of institutional directors on boards range from $13.16 \%$ in Bangladesh to $81.20 \%$ in Taiwan. Thus, depending on the context, the turning point is different. This idea can also be extended to women's representation on boards. Consequently, the addition of more female institutional directors on boards beyond a certain inflection point may induce boards to make suboptimal decisions, having a negative effect on the monitoring and improvement of economic development and therefore reducing corporate value.

Thus, based on the above arguments and extending them to gender diversity on boards, we predict a non-linear relationship between female institutional directors on boards and firm value, that is, institutional female directors on boards will have a positive effect on corporate performance, but when their presence on boards reaches a certain threshold, the firm value will then reduce (Navissi and Naiker, 2006). Accordingly, we pose the following hypothesis:

$H_{1}$ : A non-linear relationship is expected between female institutional directors on boards and firm value: female institutional directors influence firm value positively, but when they reach a certain threshold, they affect it negatively.

Although there is undoubtedly an influence of institutional investors in the decision-making process of the boards, not all of them are equally willing or able to serve this function (Almazán et al., 2005). Accordingly, previous research argues that business relationships with the company may significantly influence the preferences and incentives of the institutional investors to control corporate decisions, which suggests that some institutional investors prefer to monitor firms and exert an influence on managers, whereas others opt for information-gathering and short-term trading profits (Elyasiani and Jia, 2010). According to Bennett et al. (2003), among institutional investors there are not only legal differences, but also differences in terms of investment strategy and their incentives and resources to gather information and to engage in the governance of firms. Therefore, institutional investors cannot be considered as a homogeneous group due to their different incentives and ability to be involved in corporate governance (Almazán et al., 2005; Cornett et al., 2007; Jara-Bertin et al., 
2012; López-Iturriaga et al., 2015). In this vein, two groups of institutional investors on boards can be differentiated, according to their business objectives: pressure-sensitive (banking institutions and insurance companies) and pressure-resistant (mutual funds, investment funds and pension funds) (Brickley et al., 1988; Pound, 1988; Kochhar and David, 1996; Bhattacharya and Graham, 2007; Dong and Ozkan, 2008).

For the reasons provided in the introduction, we only focus on the role played by pressureresistant institutional directors. They have a more independent position on the firm and may therefore be less subject to pressure from the companies in which they invest and are better suited to control and impose controls on corporate managers (Almazán et al., 2005; Ruiz-Mallorquí and Santana-Martín, 2011; Jara-Bertín et al., 2012; Pucheta-Martínez and García-Meca, 2014). Pressure-resistant institutional investors face fewer conflicts of interest arising from business relationships, and can serve as a monitoring mechanism in mitigating agency problems between shareholders and managers (Brickley et al., 1988; Bhattacharya and Graham, 2007; Cornett et al., 2007). Authors such as Pound (1988), Elyasiani and Jia (2010), Ruiz-Mallorquí and Santana-Martín (2011), Muller-Kahle (2012) and Wahba and Elsayed (2014), among others, found evidence that companies with pressure-resistant institutional investors on boards are more likely to have better firm value. This finding is supported by Jara-Bertin et al. (2012), Bhattacharya and Graham (2007) and Sahu (2014), who reported a positive relationship between pressure-resistant institutional investors and firm value, given that they do not interfere with daily business activities and are better monitors of corporate managers. This idea is in line with the content hypothesis, which predicts that pressure-resistant directors may monitor managers with a lower cost than minority shareholdings with dispersed ownership (McConnell and Servaes, 1990) and, thus, the alignment effect and efficient monitoring should result in a positive relationship between pressure-resistant institutional directors and corporate value. However, based on the collusion hypothesis, when the presence of pressure-resistant institutional directors on boards reaches a certain threshold, pressure-resistant directors then entrench themselves and can achieve absolute control of firms and extract private benefits and they may also cooperate with managers, since they may get mutual benefits. Consequently, the monitoring role played by pressure-resistant directors will be ineffective due to the entrenchment and the cooperation, impacting negatively on firm 
performance. Thus, these arguments support the thesis that the disciplinary role on the management team played by pressure-resistant institutional directors on boards is limited to a concrete ownership stake in the firm, beyond which the addition of more pressure-resistant directors will not be beneficial because it will facilitate the obtaining of their personal interests, so destroying firm value, due to the fact that they have an important influence on firm management. The view of the combination of the content and collusion hypotheses is consistent with Jiao and Ye (2013), who extend the quadratic relationship shown by Jara-Bertín et al. (2012) and Navissi and Naiker (2006) between institutional directors and firm value to pressure-resistant institutional directors, reporting an inverted U-shaped relationship between firms' future performance and equity ownership by pressure-resistant institutional investors. Accordingly, there might be a quadratic influence on firm value, rather than a linear relationship. The same arguments exhibited above concerning the inflection point of female institutional directors on boards can be used for the presence of pressure-resistant female institutional directors.

To the best of our knowledge, there is no research that has analysed the impact of pressureresistant female directors on boards on firm value. Thus, this gap in the corporate governance literature has to be filled as well. Female directors are more averse to risk, may be stricter in monitoring management and may behave more ethically than male directors ${ }^{1}$, among other things (Khazanchi, 1995; Jianakopolos and Bernasek, 1998; Byrnes et al., 1999). All these aspects of female behaviour may align with, or diverge from, the interests of all shareholders, depending on the kind of institutional investors whom they represent and on the amount of female directors on corporate boards. Therefore, based on the above arguments, we can expect a non-linear relationship, specifically quadratic, between pressure-resistant female directors on boards and firm value. Thus, we posit the following hypothesis:

$H_{2}:$ A non-linear relationship is expected between pressure-resistant female institutional directors on boards and firm value: pressure-resistant female directors influence firm value positively, but when they reach a certain threshold, they affect it negatively. 


\section{EMPIRICAL DESIGN}

\section{Sample}

The sample for the panel data analysis comprises non-financial firms listed on the Madrid Stock Exchange during the period 2004-2013. We exclude financial companies both because they are under special scrutiny by financial authorities that constrain the role of their board of directors and because of their special accounting practices. The data was obtained from the Public Register of the Spanish Securities Market Commission (CNMV), from the "Sistemas de Análisis de Balances Ibéricos" (SABI) database and from the corporate and annual reports that all listed companies are required to publish since 2003, from which the specific data on female institutional directors has been obtained.

We build an unbalanced panel of 989 firm-year observations. The panel is unbalanced because during this time period some firms became public, and other firms were delisted as a consequence of mergers and acquisitions. Nevertheless, the estimations based on unbalanced panels are as reliable as those based on balanced panels (Arellano, 2003).

\section{Variables}

As the dependent variable we use Tobin's Q defined as Q_TOBIN and measured as the ratio between the market value of common stock plus book debt and total assets. Previous studies have also used Tobin's Q as an approximation of corporate performance (Eisenberg et al., 1998; Campbell and Mínguez-Vera, 2010; Kumar and Singh, 2012; Liu et al., 2013; Sacramento et al., 2013; Ibrahim and Samad, 2014; Vo and Nguyen, 2014).

Several independent variables are also used. INST_WOM_BD is defined as the percentage of female institutional directors sitting on the board. Institutional directors are appointed by institutional investors, who represent insurance and banking firms or investment funds. Following García-Meca et al. (2015) and Pucheta-Martínez and García-Meca (2014), we define RESIST_WOM_BD as the proportion of the board's female directors who are representative of pressure-resistant institutional investors (i.e. mutual and pension funds). INST_WOM_BD ${ }^{2}$ and RESIST_WOM_BD ${ }^{2}$ are defined as the square of the proportion of female institutional directors on boards and of the board's female 
directors who are representative of pressure-resistant institutional investors, respectively. These two variables introduce the moderating effect on firm value of adding a new institutional and pressureresistant female director of the board.

Several factors that may potentially influence firm value are also controlled. We define INDP_BD as the proportion of independent directors sitting on the board. Authors such as Coles et al. (2001), Chen et al. (2005), Jo and Harjoto (2011), Knyazeva et al. (2013) and Liu et al. (2013), among others, showed a positive relationship between the percentage of independent directors on the board and firm value. Another control variable used is the duality in the position of chairman of the board of directors and chief executive officer (CEO), defined as CEO_DUALITY and measured as a dummy variable equal to 1 if the same person serves simultaneously as CEO and president of the board of directors and zero otherwise. Carter et al. (2003), Chen et al. (2005), Rashid et al. (2010) and Lee and Zhang (2011) demonstrated a negative relationship between CEO duality and firm value, while other studies (Tian and Lau, 2001; Peng, 2004; Peng et al., 2007; Vo and Nguyen, 2014) showed a positive relationship. The ownership concentration is also considered as a control variable, defined as OWNCON and calculated as the proportion of shares held by shareholders holding at least $10 \%$ of the firm's stock. Sacramento et al. (2013) and Sheikh et al. (2013) reported a positive relationship between the ownership concentration and firm value. Insider ownership is denoted as INSOWN and it is measured, in line with Rashid (2013), as the percentage of stock held by directors. Previous evidence provided a positive relationship between insider ownership and firm value (Yermark, 1996; Beiner et al., 2006; Attig et al., 2009; Rashid et al., 2010; Ruiz-Mallorquí and Santana-Martín, 2011). The leverage level of the company is denoted as LEV and calculated as the ratio of book value of debt over total assets. Previous literature (Mak and Kusnadi, 2005; Ibrahim and Samad, 2014; Sahu, 2014) shows that high financial leverage was positively related to firm value. We also control for profitability, defined as ROA and calculated as the ratio of earnings before interest and taxation (EBIT) over book assets (Campbell and Mínguez-Vera, 2008). Carter et al. (2003), Campbell and Mínguez-Vera (2008), Kumar and Singh (2012) and Sacramento et al. (2013) provided evidence that firms with a high return on their assets ratio had greater potential for firm value. The proportion of institutional directors on the board is denoted as INST and is calculated as the ratio between the total 
number of institutional directors on the board and the total number of directors on the board. Some previous investigations (Bhattacharya and Graham, 2007; Kumar and Singh, 2012) report that institutional investors are negatively related to firm performance, while authors such as Chen et al. (2003), Elyasiani and Jia (2010) and Aggarwal et al. (2011) find a positive association between institutional investors and firm performance. Firm size is also considered as a control variable. It is defined as SIZE and it is calculated as the logarithm of the total assets (expressed in thousands of Euros). Mak and Kusnadi (2005), Rashid et al. (2010) and De Villiers et al. (2011) report a positive relation between company size and firm performance. We define board size as BDSIZE and it is calculated as the total number of directors on the board. Previous literature shows that board size has a negative effect on firm value (Campbell and Mínguez-Vera, 2010; Ibrahim and Samad, 2014). The sector is also controlled. Thus, we defined the industry of the company as SEC (i) and it is calculated as a dummy variable that takes the value of 1 if the company belongs to the sector in question and 0 otherwise. We base this on the Madrid Stock Exchange classification: SEC (1): Oil and energy; SEC (2): Commodities, industry, and construction; SEC (3): Consumer goods; SEC (4): Consumer services; SEC (5): Financial services and property, and SEC (6): Technology and telecommunications. The reference category is SEC (1). Authors such as Burriel et al. (2012) and Hidalgo et al. (2012) find a positive relationship between firm sector and firm performance. Finally, we also consider a dummy variable that takes into account the following two contexts: the effect of legal reform (effective equality between women and men) and the economic crisis. As these facts can be considered to have happened in similar periods: 2004 to 2007 for the pre-crisis and pre-effect of the reforms period, and 2008 to 2013 for the crisis and the period after the implementation of the 3/2007 Act. This variable is defined as DCRI_LAW and takes the value 1 if the period runs from 2008 to 2013 and 0 otherwise. A summary of all the variables is provided in Table 1.

$<$ Insert Table 1 about here $>$

\section{Methodology}

We run the following model to test our hypotheses: 


$$
\begin{aligned}
& \mathrm{Q}_{-} \mathrm{TOBIN}_{\mathrm{it}}=\alpha+\beta_{1} \mathrm{INST}_{-} \mathrm{WOM}_{-} \mathrm{BD}_{\mathrm{it}}+\beta_{2} \mathrm{INST}_{-} \mathrm{WOM}_{-} \mathrm{BD}_{\mathrm{it}}^{2}+\beta_{3} \mathrm{RESIST}_{-} \mathrm{WOM}_{-} \mathrm{BD}_{\mathrm{it}}+ \\
& \beta_{4} \text { RESIST_WOM_BD }_{\text {it }}^{2}+\beta_{5} \mathrm{INST}_{\mathrm{it}}+\beta_{6} \mathrm{NDP}_{-} \mathrm{BD}_{\mathrm{it}}+\beta_{7} \mathrm{CEO}_{-} \mathrm{DU} \text { ULITY }{ }_{\mathrm{it}}+\beta_{8} \mathrm{OWNCON}_{\mathrm{it}}+\beta_{9} \mathrm{INSOWN}_{\mathrm{it}} \\
& +\beta_{10} \mathrm{LEV}_{\mathrm{it}}+\beta_{11} \mathrm{ROA}_{\mathrm{it}}+\beta_{12} \text { BDSIZE }_{\mathrm{it}}+\beta_{13} \mathrm{SIZE}_{\mathrm{it}}+\beta_{14} \cdot \mathrm{DCRI}_{-} \mathrm{LAW}_{\mathrm{it}}+\beta_{15} \mathrm{SEC}(\mathrm{i})_{\mathrm{it}}+\mu_{\mathrm{it}+}+\varepsilon_{\mathrm{it}}
\end{aligned}
$$

where $\mu_{\mathrm{it}}$ represents firm-fixed and year-fixed effects and $\varepsilon_{\mathrm{it}}$ the error. Firm-fixed effects aim at capturing constant and non-observable characteristics of the firms that are potentially correlated to the dependent variable. We consider year- and firm-fixed effects to control for year- and firm-specific effects on the firm value.

The relationship between board composition and corporate performance may cause endogeneity problems (Demsetz and Villalonga, 2001; Hermalin and Weisbach, 1998; Villalonga and Amit, 2006). Thus, we also consider the potential endogeneity between firm value and female directors on boards. In other words, do these directors lead to high corporate performance, or do firms with high firm value attract female directors onto their boards? Although the causality between female directors and firm performance is more likely to run from directors to performance, it is also possible that firm value could affect board composition. To address this problem, we estimate our model using the instrumental variables method. More specifically, we implement the two-stage least squares method (2SLS) (Anderson et al., 2003; Klock et al., 2005) to instrument the corporate governance variables (INST_WOM_BD and RESIST_WOM_BD). To test the validity of the instruments, we use the Hansen test of over-identifying restrictions, which distributes as $\mathrm{Chi}^{2}$ and tests the null hypothesis of correct model specification and valid over-identifying restrictions, i.e. the validity of instruments (Baum, 2006). The rejection of the null hypothesis means that either or both assumptions are questionable. Thus, the Hansen test allows us to test the absence of a correlation between the instruments and the error term and, therefore, to check the validity of the selected instruments.

\section{RESULTS}

\section{Descriptive analysis}

Table 2 offers the mean value, the standard deviation and the $10^{\text {th }}, 50^{\text {th }}$ and $90^{\text {th }}$ percentiles of the variables.

$<$ Insert Table 2 about here $>$ 
Table 2 shows that the Q_TOBIN (the market value of common stock plus book debt divided by total assets) of the firms, on average, is 2.18 . Concerning board composition, we appreciate that female institutional directors account for $3.82 \%$ of directorships on boards, while pressure-resistant female institutional directors represent $3.37 \%$ on boards. The proportion of institutional and independent directors on boards is, on average, $43.41 \%$ and $32.30 \%$, respectively, the ownership concentration represents $41.60 \%$ and the insider ownership accounts for $26.86 \%$. The level of leverage is, on average, $57.90 \%$ and the return on assets $1 \%$. The size of the firm, on average, is 13.13 (the logarithm of the total assets expressed in thousands of Euros) and board size is 10.83 members, while CEO duality on boards represents $36 \%$. Meanwhile, $10 \%$ of the companies in the sample belong to the oil and energy sector (SEC1), 28\% each to the commodities, industry, and construction sector (SEC2) and the consumer goods sector (SEC3), 14\% to the consumer services sector (SEC4), 15\% to financial services and property (SEC5) and 5\% to the technology and telecommunications sector (SEC6). Finally, $66 \%$ of the whole period of analysis is collected from 2008 to 2013.

To test for multicollinearity, we have calculated the correlation matrix presented in Table 3 . The correlation between most of the pairs is low, generally below 0.3 . None of the correlation coefficients is high enough $(>0.80)$ to cause multicollinearity concerns (see Archambeault and DeZoort, 2001; Carcello and Neal, 2000), except the pair INST_WOM_BD-RESIST_WOM_BD, which is correlated by construction because this pair is between corporate governance variables. Additionally, the corporate governance variables (INST_WOM_BD and RESIST_WOM_BD), which show a high correlation, are not included simultaneously in the model. Therefore, we can conclude that the models are free of multicollinearity problems. The variance inflation factors (VIF) have also been calculated and none was so high as to indicate multicollinearity problems (see Neter et al., 1985), since all values are below 10, which is generally used as a critical threshold according to Haan (2002). $<$ Insert Table 3 about here $>$

\section{Univariate analysis}

Table 4 presents the mean values of the independent variables between firms with a Q_TOBIN higher than or equal to 1.57 and with a Q_TOBIN lower than 1.57 to test for the presence of 
differences in means between the two groups of firms. The median (1.57) of the Q_TOBIN was used to create the two groups.

$<$ Insert Table 4 about here $>$

As shown in Table 4, the difference in the means of the variables denoting the percentage of female institutional directors on boards (INST_WOM_BD) is positive and statistically significant. This result suggests that companies with a Q_TOBIN higher than or equal to 1.57 have a higher presence of female institutional directors on their boards than firms with a Q_TOBIN lower than 1.57. Thus, we may conclude that female institutional directors on boards have a positive influence on firm value. These results are consistent with earlier papers which focus on gender diversity and firm value (Atkinson et al., 2003; Liu et al., 2013; Lückerath-Rovers, 2013; Pathan and Faff, 2013; Garba and Abubakar, 2014; Martín-Ugedo and Mínguez-Vera, 2014). It can also be observed that the difference in the means of the variables representing pressure-resistant institutional women directors on boards (RESIST_WOM_BD) is also positive and statistically significant. These findings show that firms with a higher firm value have more pressure-resistant female institutional directors on boards than companies with lower levels of corporate performance. On the whole, and in line with Saunders et al. (2003), Cornett et al. (2007) and Chen et al. (2008), our results suggest that female institutional directors and pressure-resistant female directors on boards enhance firm value. This finding is supported by Jara-Bertín et al. (2012), Muller-Kahle (2012) and Wahba and Elsayed (2014), who show that pressure-resistant institutional investors have better firm value than other types of institutional investors such as pressure-sensitive institutional investors. Thus, female institutional investors and pressure-resistant female institutional investors appear to exert control on boards to enhance firm value.

\section{Multivariate analysis}

In Table 5 we offer the results of the linear regression, specifically quadratic, for institutional and pressure-resistant women directors on boards in Model 1 and 2, respectively. Furthermore, one alternative model, a logarithmic model, has also been run. The logarithmic model uses the logarithm on both dependent and independent or explanatory variables. Given that the $\mathrm{R}^{2}$ is higher for the linear 
regression than for the logarithmic model, the first one fits better than the second one, and we will consequently test the hypotheses with the linear model. Therefore, the findings of the logarithmic regression for institutional and pressure-resistant women directors on boards are not reported.

$<$ Insert Table 5 about here $>$

In Model 1, we analyse whether female institutional directors on boards have an influence on firm value, while in Model 2, we solely examine the repercussions of having pressure-resistant institutional women directors on boards on corporate performance. The statistical tests show that the two models are statistically significant. As predicted, the variables representing female institutional directors on boards in a linear (INST_WOM_BD) and non-linear way (INST_WOM_BD²), specifically quadratic, present the expected signs and are statistically significant. Consistent with hypothesis 1 , the results suggest that the proportion of female institutional directors on boards has a positive impact on firm value, but when the percentage of institutional women on boards reaches a certain threshold, namely $11.72 \%$, they have a negative effect on firm value. Thus, this figure suggests that the inflection point is $11.72 \%$ on boards, and therefore that the active monitoring role of the management team is played by female institutional directors on boards only until their presence reaches this, but beyond this turning point, they play a passive and ineffective monitoring role. A similar threshold is also obtained by Kumar (2004) for institutional ownership. This evidence supports the thesis that there is an optimal percentage of female institutional directors on boards, beyond which $(11.72 \%)$ the addition of one female institutional director on a board will have a negative impact on corporate value. Consequently, the firm performance is positively associated with the presence of female institutional directors on boards in the $0-11.72 \%$ range of institutional women representation, and negatively associated when the proportion of female institutional directors on boards exceeds $11.72 \%$. A large number of previous studies provide evidence that institutional investors on boards contribute to an increase in firm value (e.g. Tian and Lau, 2001; Chen et al., 2008; Yuan et al., 2008; Elyasiani and Jia, 2010; Lee and Zhang, 2011), while authors such as Drago et al. (2011), Kumar and Singh (2012) and Welch and Wang (2013), among others, find that institutional investors are negatively associated with firm value. Frink et al. (2003) report an inverted U-shaped relationship between gender diversity and organization performance. In the same vein, Haddaji (2009) and Van 
Essen et al. (2013) show that an inverted U-shaped relationship exists between institutional blockholders' ownership and firm value, and Jara-Bertín et al. (2012) demonstrate that in common law countries there is a U-shaped relation between institutional ownership and firm value, while in civil law countries there is an inverted U-shaped relation. Kumar (2004), Navissi and Naiker (2006), Al Farooque et al. (2007) and Rashid (2012) find that there is a nonlinear relationship between institutional shareholding and firm value. This evidence supports our findings and we can conclude that there is a non-linear association, namely an inverted U-shaped, between female institutional directors on Spanish boards and corporate performance. Thus, our results are in line with the view that as the percentage of female institutional directors increases, firm value enhances, suggesting the supervision (contest) hypothesis, but when their presence on boards reaches a certain threshold, female institutional directors on boards reduce corporate performance because as power is shared among increasingly fewer people, the restriction on the owners of this power may lead to private benefits, suggesting in this case the expropriation or collusion hypothesis.

To test hypothesis 2, we use Model 2, in which we observe that the variables denoting pressure-resistant female institutional directors on boards (RESIST_WOM_BD and RESIST_WOM_BD ${ }^{2}$ ) offer the expected direction and are statistically significant. Accordingly, we cannot reject the second hypothesis and we may conclude that, as predicted, firm value enhances with an increase in pressure-resistant institutional women directors on boards up to a point, $12.71 \%$, beyond which further increases in pressure-resistant female institutional directors on boards are associated with decreases in firm value. Our findings therefore support the assertion that corporate value is positively related to the presence of pressure-resistant female institutional directors on boards in the $0 \%$ and $12.71 \%$ range of representation of pressure-resistant institutional women, and is negatively related when the percentage of pressure-resistant female institutional directors on boards is higher than $12.71 \%$. Thus, this evidence suggests that an approximate gender balance is best, as evidenced by the fact that the optimal point for pressure-resistant women directors on boards is $12.71 \%$, with a maximum of $32.30 \%$ in female representation, which is close to half $(50 \%)$ of the representation on boards. This idea is consistent with Frink et al. (2003), who show that the optimal percentage for board gender diversity is when it is balanced, or near the midpoint. In line with female institutional directors, 
the findings also suggest an inverted $\mathrm{U}$-shaped relationship between pressure-resistant female ownership and corporate performance, which is corroborated by Navissi and Naiker (2006), who report an inverted U-shaped association between institutional investors and firm value. Based on agency theory, as the presence of pressure-resistant female directors on boards increases, it implies more engagement in the control of managers and, as a result, firm value enhances, but when they reach a threshold (12.71\%) on boards, they achieve excessive power and become entrenched and they can thereby act in ways that harm the interests of other shareholders and lead to reduced firm value. This result also seems to suggest that female directors on boards who represent pressure-resistant institutional investors use firm value as a control mechanism relating to the management team, in line with the monitoring or contest hypothesis, but when their ownership is higher than $12.71 \%$ on boards, the entrenchment or expropriation hypothesis prevails.

With regard to the control variables, we can observe that independent directors on boards (INDP_BD), board size (BDSIZE), firm size (SIZE), period for crisis and the period after the implementation of the 3/2007 Act (DCRI_LAW) and sector (SEC(i)) present the expected sign and they are statistically significant. Therefore, these findings show that companies with a high proportion of independent directors on boards, with big firm size and that belong to all the sectors analysed are more likely to enhance firm value, while big board size and the period for crisis and the period after the implementation of the 3/2007 Act have a negative influence on firm performance. The remainder of the control variables report insignificant values.

As previously noted, we perform some further analysis to address the endogeneity problem. We run new estimates using the two-stage least squares method. For the sake of brevity, we do not report the results, which are consistent with our main findings; i.e. the estimates of the two-stage leastsquares method corroborate the results previously reported.

\section{CONCLUSIONS}

Previous research has focused on the relationship between institutional investors and firm value (Brickley et al., 1988; Peng, 2004; Yuan et al., 2008; Jo and Harjoto, 2011; Wahba and Elsayed, 
2014), showing that this is one issue that has generated the most interest and controversy over recent years.

The aim of this paper is to analyse how female institutional directors have an impact on firm value. Specifically, we examine the effect of female institutional directors on boards as a whole on firm value; and we also explore the role played by a particular type of female institutional director, pressure-resistant female institutional directors, whose business activity is not related to the company in which they hold a directorship (mutual, pension and investment funds). The role of the pressuresensitive female institutional directors has not been analysed, given their low presence on Spanish boards of listed firms.

Our results show that female institutional directors have diverse incentives to engage in corporate governance. When female institutional directors are considered as a whole, the findings demonstrate that there is a positive relationship between female institutional directors sitting on boards and firm value, but when their presence on boards reaches the inflection point of $11.72 \%$, firm value decreases. Depending on business relations, we find that female directors who are pressure-resistant (i.e. from mutual funds and pension funds) on boards have a positive effect on firm value. However, as shown from female institutional directors taken as a whole, when the presence of pressure-resistant female directors on boards reaches $12.71 \%$, they have a negative influence on firm value. Thus, our results also confirm the role of pressure-resistant female institutional directors, suggesting that when female institutional directors do not maintain a business relation with the firms in which they hold a directorship, such as pressure-resistant female institutional directors, they behave in the same way as female institutional directors as a whole. These findings suggest an inverted U-shaped relationship between institutional and pressure-resistant female directors on boards and corporate performance. The above turning points imply that female institutional directors and pressure-resistant female institutional directors appear to actively monitor managerial behaviour until their presence on boards reaches these inflection points, in line with the supervision (monitoring or contest) hypothesis, but beyond them, they then stop monitoring management, consistent with the collusion, expropriation or entrenchment hypothesis. Overall, the impact of female institutional directors cannot be considered only as a whole, but must be examined conditionally on the stake of the directors on boards. 
Our results have different implications for the corporate governance debate. First, the findings of this analysis imply that in civil law environments such as Spain, characterized by a higher ownership concentration, an increase of institutional and pressure-resistant female directors on boards below the inflection points $(11.72 \%$ and $12.71 \%$, respectively) can align the interest between owners and managers, although when these proportions exceed these points, they can then monitor the company and have opportunistic behaviours. These results support the idea that the addition of more female institutional and pressure-resistant female institutional directors beyond this optimal proportion will affect corporate performance negatively. Given the active public debate prompted by mandatory gender quotas on boards, our evidence suggests that policy-makers should encourage the presence of women directors on boards, recommending gender quotas on boards rather than imposing them, since the economic outcomes of compulsory gender diversity quotas on boards may be controversial (see Valsan, 2015). This view is in line with the strong opposition to binding gender quotas on boards from Anglo-American countries (Valsan, 2015) and Grant Thornton's (2013) study, which support a voluntary initiative to promote female representation on boards. Secondly, policymakers have focused on examining the board composition and have paid little attention to the ownership structure. Therefore, our results should encourage policymakers to change their perspectives on the different types of shareholders in corporate governance, since these may have an effect on corporate performance. Thirdly, another implication that can be derived from this analysis is that pressureresistant female institutional directors who do not maintain business relations with the firm where they hold a directorship behave in the same way as female institutional directors when they are considered as a whole, impacting on firm value. Pressure-resistant directors usually do not find their managerial monitoring role compromised, given that they do not have to safeguard their business relationships with the firm. However, potential business relations with the firm in the future (e.g. if the firm is interested in hiring a pension fund for their employees) may also support the argument that they may align with management (Van Nuys, 1993). Thus, among female institutional investors, directors representing pension, mutual and investment funds (pressure-resistant institutional directors) on boards play an important role in corporate governance since they affect corporate performance. Accordingly, companies should revisit the presence of this type of female institutional director on 
boards. Our findings are relevant for European countries that are characterized by weak corporate governance and where the predominant agency conflict is the expropriation of minority shareholders' wealth by large shareholders. Finally, due to the quadratic association between female institutional and pressure-resistant female directors on boards and corporate performance, the monitoring and disciplinary role played by them is limited to the ownership stake that they hold in the firm. Thus, this finding may have implications for stakeholders, particularly shareholders, and potential investors because, while these female directors may be able to promote good corporate governance practices, affecting firm value, they may also not encourage such practices.

The limitations of this study are as follows. Firstly, we would like to highlight that although most of the female directors on Spanish boards of listed firms are institutional directors, their presence is still low, particularly female pressure-sensitive directors. However, the percentage of women on the corporate bodies of firms has increased in recent years due, in part, to the publication of recommendations and the Act 3/2007, "The Equality Law", which was issued in 2007 in order to recommend a gender quota of $40 \%$ on boards of listed companies, to be reached by 2015 . Finally, it is possible that there are unknown factors that could have an impact on our dependent variable. While we have controlled for as many factors as possible based on theory and previous research, empirical and theoretical limitations prevent us from knowing whether all of the important influences have been controlled for and addressed.

This study could give rise to future lines of research. First, future research may study the participation patterns of female institutional directors on corporate boards of companies controlled by individual owners, families and firms mainly controlled by the state, which would reflect the divergence of the interests of their owners in the management of the companies. Finally, it would be interesting to examine the repercussions of female institutional directors in smaller and medium-sized companies, because we have only analysed the big companies, and the findings may not be identical. 


\section{Notes}

${ }^{1}$ Various features associated with the female leadership style mean that women directors may not have the same impact on board functions, and as a result, on corporate performance, as men directors. The essential differences between female and male leadership styles may be because women have different human capital and because there are innate differences between men's and women's personalities, among others. This may explain why women ask more questions than men and why women lead to more civilized behaviour and sensitivity to other perspectives, since they bring different concerns, perspectives, sensibilities and experiences and provide richer and deeper discussions and more constructive dissent. Furthermore, female leadership style may also explain why women are perceived to be more risk-averse than men, and will thus be less trusted to make risky decisions, why female directors may exercise greater control over management and may be quicker to detect opportunistic behaviours than male counterparts and why female directors may be stricter in monitoring management and behave more ethically than male directors, because women prepare more conscientiously for meetings, attend more meetings, enhance the attendance behaviour of men directors, are stricter complying with the norms and behave more prudently. Finally, the fact that women investors may be less sophisticated and sensitive financially than male investors may also be a consequence of the low level of risk that females prefer, as well as their financial conservatism, characteristics of the female leadership style.

${ }^{2}$ The term "more civilized behaviour" can be defined as being more ethical, more constructive, more conscientious, more tolerant, more peaceful and more moderate, among others.

\section{References}

Abdelsalam, O., El-Masry, A. \& Elsegini, S. 2008. Board composition, ownership structure and dividend policies in an emerging market: Further evidence from CASE 50. Managerial Finance, 34(12): 953-964.

Act 3/2007, of 22 March, for Effective Equality between Women and Men.

Adams, R. B. \& Ferreira, D. 2009. Women in the Boardroom and their impact of governance and performance. Journal of Financial Economics, 94(2): 291-309.

Aggarwal, R., Erel, I., Ferreira, M. \& Matos, P. 2011. Does governance travel around the world? Evidence from institutional investors. Journal of Financial Economics, 100(1): 154-181.

Ahl, H. 2006. Why research on women entrepreneurs needs new directions. Entrepreneurship Theory and Practice, 30(5): 595-621.

Al Farooque, O. A., Van Zijl, T., Dunstan, K. \& Karim, A. W. 2007. Ownership structure and corporate performance: evidence from Bangladesh. Asia-Pacific Journal of Accounting \& Economics, 14(2): 127-149.

Aldama Report 2003. Informe de la Comisión Especial para el Fomento de la transparencia y la Seguridad en los Mercados Financieros y en las Sociedades Cotizadas. Madrid: Ministerio de Economía y Hacienda. 
Ali, M., Ng, Y.L. \& Kulik, C. 2014. Board age and gender diversity: a test of competing linear and curvilinear predictions. Journal of Business Ethics, 125(3): 497-512.

Allen, J. W. 2001. Private Information and Spin-off Performance. The Journal of Business, 74(2): $281-306$

Almazán, A., Hartzell, J. C. \& Starks, L. T. 2005. Active institutional shareholders and costs of monitoring: Evidence from executive compensation. Financial Management, 34(4): 5-34.

Anderson, R. C, Mansi, S. A. and Reeb, D.M. 2003. Founding family ownership and the agency cost of debt. Journal of Financial Economics, 68(2): 263-285

Archambeaut, D. \& DeZoort, F. T. 2001. Auditor opinion shopping and the Audit Committee: An analysis of suspicious auditor switches. International Journal of Auditing, 5(1): 33-52.

Arellano, M. 2003. Panel data econometrics. Oxford: Oxford University Press.

Atkinson, S. M., Baird, S. B. \& Frye, M. B. 2003. Do female mutual fund managers manage differently? Journal of Financial Research, 26(1): 1-18.

Attig, N., El Ghoul, S. \& Guedhami, O. 2009. Do multiple large shareholders play a corporate governance role? Evidence from East Asia. Journal of Financial Research, 32(4): 395-422.

Barber, B. M. \& Odean, T. 2001. Boys will be boys: gender, overconfidence, and common stock investment. Quarterly Journal of Economics, 116(1): 261-292.

Baum, F. C. 2006. An introduction to modern econometrics using Stata. Texas: Stata Press.

Beiner, S., Drobetz, W., Schmid, M. M. \& Zimmermann, H. 2006. An integrated framework of corporate governance and firm valuation. European Financial Management, 12(2): 249-283.

Bennett, J. A., Sias, R. W. \& Starks, L. T. 2003. Greener pastures and the impact of dynamic institutional preferences. Review of Financial Studies, 16(4): 1203-1238.

Bhattacharya, P. S. \& Graham, M. 2007. Institutional ownership and firm value: evidence from Finland?, Working Paper, School of Accounting, Economics and Finance, Faculty of Business and Law, Deaking University, Melbourne.

Bilimoria, D. 2000. Building the business case for women corporate directors. Women on Corporate Boards of Directors, 14: 25-40. 
Booth, J. R. \& Deli, D. N. 1999. On executives of financial institutions as outside directors. Journal of Corporate Finance, 5(3): 227-250.

Boubakri, N. \& Ghouma, H. 2010. Control/ownership structure, creditor rights protection, and the cost of debt financing: International evidence. Journal of Banking and Finance, 34(10): 24812499.

Brewer, M. B. 1991. The social self: On being the same and different at the same time. Personality and Social Psychology Bulletin, 17(5): 475-482.

Brickley, J. A., Lease, R. C. \& Smith, C. W. 1988. Ownership structure and voting on antitakeover amendments. Journal of Financial Economics, 20: 267-291.

Burgess, Z. \& Tharenou, P. 2002. Women board directors: Characteristics of the few. Journal of Business Ethics, 37(1): 39-49.

Burke, R. J. 1997. Women on corporate Boards of Directors: and needed resource. Journal of Business Ethics, 16(9): 909-915.

Burriel, P., Labrador, M. \& Brusca, I. 2012. Factores explicativos de la rentabilidad: Género y Responsabilidad Social Empresarial. Paper presented at XV Congreso de la Asociación Española de Profesores Universitarios de Contabilidad. Cádiz.

Byrnes, J., Miller, D. \& Schafer, W. 1999. Gender Differences in Risk Taking: A Meta-analysis. Psychological Bulletin, 125(3): 367-383.

Campbell, K. \& Mínguez-Vera, A. M. 2008. Gender diversity in the Boardroom and firm financial performance. Journal of Business Ethics, 83(3): 435-451.

Campbell, K. \& Mínguez-Vera, A. M. 2010. Female board appointments and firm valuation: short and long-term effects. Journal of Management \& Governance, 14(1): 37-59.

Carcello, J. V. \& Neal, T. L. 2000. Audit Committee composition and auditor reporting. The Accounting Review, 75(4): 453-467.

Carleton, W. T., Nelson, J. A. \& Weisbach, M. S. 1998. The influence of institutions on corporate governance through private negotiations: evidence from TIAAF-CREF", Journal of Finance, 53(4): 1335-1362. 
Carter, D., Simkins, B. \& Simpson, W. 2003. Corporate governance, board diversity, and firm value. The Financial Review, 38(1): 33-53.

Carter, D. A., D'Souza, F., Simkins, B. J., \& Simpson, W. G. 2010. The gender and ethnic diversity of US boards and board committees and firm financial performance. Corporate Governance: An International Review, 18(5): 396-414.

Chen, C. R., Guo, W., \& Mande, V. 2003. Managerial ownership and firm valuation: Evidence from Japanese firms. Pacific-Basin Finance Journal, 11(3): 267-283.

Chen, J., Blenman, L., \& Chen, D. H. 2008. Does institutional ownership create values? The New Zealand case. Quarterly Journal of Finance and Accounting, 109-124.

Chen, Z., Cheung, Y. L., Stouraitis, A., \& Wong, A. W. 2005. Ownership concentration, firm value, and dividend policy in Hong Kong. Pacific-Basin Finance Journal, 13(4): 431-449.

Chirinko, R. S., van Ees, H., Garretsen, H., \& Sterken, E. 1999. Firm value, financial institutions and corporate governance in the Netherlands. CESifo Working Paper.

Christopher, J. 2010. Corporate governance-A multi-theoretical approach to recognizing the wider influencing forces impacting on organizations. Critical Perspectives on Accounting, 21(8): $683-695$.

Chung, R., Firth, M., \& Kim, J. B. 2002. Institutional monitoring and opportunistic earnings management. Journal of Corporate Finance, 8(1): 29-48.

Coles, J. W., McWilliams, V. B., \& Sen, N. 2001. An examination of the relationship of governance mechanisms to performance. Journal of Management, 27(1): 23-50.

Cornett, M. M., Marcus, A. J., Saunders, A. \& Tehranian, H. 2007. The impact of institutional ownership on corporate operating performance. Journal of Banking \& Finance, 31(6): $1771-94$

De Miguel, A., Pindado, J. \& De la Torre, C. 2004. Ownership structure and firm value: New evidence from Spain. Strategic Management Journal, 25(12): 1199-1207.

De Villiers, C., Naiker, V. \& van Staden, C. J. 2011. The effect of board characteristics on firm environmental performance. Journal of Management, 0149206311411506. 
Del Guercio, D. \& Hawkins, J. 1999. The motivation and impact of pension fund activism. Journal of Financial Economics, 52(3): 293-340.

Demsetz, H. \& Villalonga, B. 2001. Ownership structure and corporate performance. Journal of Corporate Finance, 7(3): 209-233.

Dong, H. 2014. Essays on Mutual Fund Strategies and Investor Characteristics. UNIVERSIDAD CARLOS III DE MADRID. Tesis Doctoral. Doctorado en Economía de la Empresa y Métodos Cuantitativos. Departamento de Economía de la Empresa. Mayo, 2014.

Dong, M. \& Ozkan, A. 2008. Institutional investors and director pay: an empirical study of UK companies. Journal of Multinational Financial Management, 18(1): 16-29.

Drago, C., Millo, F., Ricciuti, R. \& Satella, P. 2011. The Role of Women in the Italian Network of Boards of Directors, 2003-2010. Working Paper Series Department of Economics University of Verona, (ISSN: 2036-2919 (paper), 2036-4679 (online)).

Eisenberg, T., Sundgren, S. \& Wells, M. T. 1998. Larger board size and decreasing firm value in small firms. Journal of Financial Economics, 48(1): 35-54.

Elyasiani, E. \& Jia, J. 2010. Distribution of institutional ownership and corporate firm value. Journal of Banking \& Finance, 34(3): 606-620.

Erhardt, N., Werbel, J. and Shrader, C. 2003. Board of director diversity and firm financial performance. Corporate Governance: An International Review, 11(2), 102-110.

Faccio, M. \& Lang, L. H. 2002. The ultimate ownership of Western European corporations. Journal of Financial Economics, 65(3): 365-395.

Farinha, J. 2003. Dividend policy, corporate governance and the managerial entrenchment hypothesis: an empirical analysis. Journal of Business Finance \& Accounting, 30(9-10): $1173-1209$.

Ferreira, M. A. \& Matos, P. 2008. The colors of investors' money: The role of institutional investors around the world. Journal of Financial Economics, 88(3): 499-533.

Fondas, N. \& Sassalos, S. 2000. A different voice in the boardroom: how the presence of women directors affects board influence over management. Global Focus, 12(2): 13-22. 
Francoeur, C., Labelle, R. \& Sinclair-Desgnané, B. 2008. Gender diversity in Corporate Governance and top management. Journal of Business Ethics, 81(1): 83-95.

Frink, D. D., Robinson, R. K., Reithel, B., Arthur, M. M., Ammeter, A. P., Ferris, G. R., Kaplan, D. M. \& Morrisette, H. S. 2003. Gender demography and organization performance A two-study investigation with convergence. Group \& Organization Management, 28(1): 127-147.

Garba, T. \& Abubakar, B. A. 2014. Corporate board diversity and financial performance of insurance companies in Nigeria: An application of panel data approach. Asian Economic and Financial Review, 4(2): 257-277.

García-Meca, E., López-Iturriaga, F. \& Tejerina, F. 2015. Institutional investors on board. Does their behaviour influence corporate finance?. Journal of Business Ethics, Forthcoming.

García-Osma, B. \& Gill de Albornoz-Noguer, B. 2007. The effect of the board composition and its monitoring committees on earnings management: Evidence from Spain. Corporate Governance: An International Review, 15(6): 1413-1428.

Gillan, S. L. \& Starks, L. T. 2003. Corporate governance, corporate ownership, and the role of institutional investors, a global perspective. Journal of Applied Corporate Finance, 13(2): $4-22$.

Giner, B. \& Pardo, F. 2015. How ethical are managers' goodwill impairment decisions in Spanishlisted firms?. Journal of Business Ethics. 132(1): 21-40.

Grant Thornton. 2013. Women in senior management: Setting the stage for growth. Available at: www.grantthornton.ie

Gómez-Ansón, S. 2005. Diversidad de género en los consejos de administración de las sociedades cotizadas y cajas de ahorros españolas. Papeles de la Fundación de Estudios Financieros, 12.

Gulzar, M. A. \& Wang, Z. 2011. Corporate Governance characteristics and earnings management: Empirical evidence from Chinese listed firms. International Journal of Accounting and Financial Reporting. 1, (1): 134-151.

Haan, C. T. 2002. Statistical methods in hydrology. (second version). Blackwell Publishing.

Haddaji, W. 2009. Corporate Governance and corporate control: Evidence from trading. Doctoral dissertation, Duke University. 
Han, K. C., Lee, S. H. \& Suk, D. Y. 1999. Institutional shareholders and dividends. Journal of Financial and Strategic Decisions, 12(1): 53-62.

Heidrick \& Struggles. 2011. Challenging board performance. European Report on corporate governance: Heidrick \& Struggles.

Heidrick \& Struggles. 2014. Towards dynamics governance 2014. European corporate governance report. Chicago, IL: Heidrick \& Struggles.

Hermalin, B. E. \& Weisbach, M. S. 1998. Endogenously chosen boards of directors and their monitoring of the CEO. American Economic Review, 96-118.

Hidalgo, R., García, E. \& Demetrio, S. 2012. ¿Impacta la estructura del Gobierno Corporativo en la rentabilidad empresarial?. Paper presented at al XV Congreso de la Asociación Española de Profesores Universitarios de Contabilidad. Cádiz.

Hillman, A. J. \& Dalziel, T. 2003. Boards of directors and firm value: Integrating agency and resource dependence perspectives. Academy of Management Review, 28(3) 383-396.

Hillman, A. J., Withers, M. C. \& Collins, B. J. 2009. Resource dependence theory: A review. Journal of Management, 35(6) 1404-1427.

Hovakimian, A. \& Li, G. 2010. Shareholder investment horizons and payout policy. Available at SSRN 1571757.

Hu, Y. \& Izumida, S. 2008. Ownership concentration and corporate performance: a causal analysis with Japanese panel data. Corporate Governance: An International Review, 16(4): 342-58.

Huse, M. \& Solberg, A. G. 2006. Gender-related boardroom dynamics: How Scandinavian women make and can make contributions on corporate boards. Women in Management Review, 21(2): 113-130.

Huse, M., Nielsen, S. \& Hagen, I. M. 2009. Women and employee-elected board members, and their contributions to board control tasks. Journal of Business Ethics, 89(4): 581-597.

Huson, M. R. 1997. Does governance matter? Evidence from CalPERS interventions. Unpublished working paper, University of Alberta, Edmonton. 
Ibrahim, H. \& Samad, F. A. 2014. Corporate governance mechanisms and performance of publiclisted family-ownership in Malaysia. International Journal of Economics and Finance, 3(1): $105-115$.

Jacobson, R. \& Aaker, D. 1993. Myopic management behaviour with efficient, but imperfect, financial markets: a comparison of information asymmetries in the US and Japan. Journal of Accounting and Economics, 16(49): 383-405.

Jara-Bertín, M., López-Iturriaga, F. \& López-de-Foronda, O. 2012. Does the influence of institutional investors depend on the institutional framework? An international analysis, Applied Economics, 44(3): 265-278.

Jensen, M. C. 1986. Agency costs of free cash flow, corporate finance, and takeovers. The American Economic Review, 76(2): 323-329.

Jensen, M. C. \& Meckling, W. H. 1976. Theory of the firm: managerial behavior, agency costs and ownership structure. Journal of Financial Economics, 3(4): 305-360.

Jianakoplos, N. \& Bernasek, A. 1998. Are Women More Risk Averse? Economic Inquiry, 36(4): $620-630$.

Jiao, Y. \& Ye, P (2013). Public pension fund ownership and firm performance. Review of Quantitative Finance and Accounting, 40(3) 571-590.

Jo, H. \& Harjoto, M. A. 2011. Corporate governance and firm value: The impact of corporate social responsibility. Journal of Business Ethics, 103(3): 351-383.

Johnsen, G. J. \& McMahon, R. G. 2005. Owner-manager gender, financial performance and business growth amongst SMEs from Australia's business longitudinal survey. International Small Business Journal, 23(2): 115-142.

Johnson, J. L., Daily, C. M. \& Ellstrand, A. E. 1996. Boards of Directors: a review and research agenda. Journal of Management, 22(3): 409-438.

Johnson, R. A. \& Greening, D. W. 1999. The effects of corporate governance and institutional ownership types on corporate social performance. Academy of Management Journal, 42(5): 564-576. 
Karpoff, J. M. 1999. The impact of shareholder activism on target companies: a survey of empirical findings. Unpublished working paper, University of Washington, Seattle, WA.

Khazanchi, D. 1995. Unethical behavior in information systems: The gender factor. Journal of Business Ethics, 14(9): 741-749.

Kirchmaier, T. \& Grant, J. 2005. Corporate ownership structure and performance in Europe. European Management Review, 2(3): 231-245.

Klock, M. S., Mansi, S. A. and Maxwell, W.F. 2005. Does corporate governance matter to bondholders? Journal of Financial and Quantitative Analysis, 40(4): 693-719.

Knouse, S. B. \& Dansby, M. R. 1999. Percentage of work-group diversity and work-group effectiveness. The Journal of Psychology, 133: 486-494.

Knyazeva, A., Knyazeva, D. \& Raheja, C. G. 2013. The Benefits of Focus vs. Heterogeneity: Dissimilar Directors and Coordination within Corporate Boards. Unpublished working paper.

Kochhar R. \& David P. 1996. Institutional investors and firm innovation: a test of competing hypotheses. Strategic Management Journal, 17(1): 73-84.

Kravitz, D. A. 2003. More women in the workplace: Is there a payoff in firm performance? Academy of Management Executive, 17(3): 148-149.

Kumar, J. 2004. Does Corporate Governance Influence Firm Value?. Evidence from Indian Firms. Journal of Entrepreneurial Finance and Business Ventures, 9(2): 61-92.

Kumar, N. \& Singh, J. P. 2012. Outside directors, corporate governance and firm value: Empirical evidence from India. Asian Journal of Finance \& Accounting, 4(2): 39-55.

La Porta, R., López de Silanes, F. \& Shleifer, A. 1999. Corporate ownership around the world. Journal of Finance, 54(2): 471-517.

Lee, J. W. \& Zhang, Z. 2011. Ownership Structure, Corporate Governance and Firm Value: Evidence from Chinese Listed Companies. In Corporate Governance and Firm Value: Evidence from Chinese Listed Companies (December 16, 2010). Finance and Corporate Governance Conference.

Levine, R. 1999. Law, finance, and economic growth. Journal of Financial Intermediation, 8(1): $8-35$. 
Levine, R., Loayza, N. \& Beck, T. 2000. Financial intermediation and growth: Causality and causes. Journal of Monetary Economics, 46(1): 31-77.

Lin, F. 2010. A panel threshold model of institutional ownership and firm value in Taiwan. International Research Journal of Finance and Economics, 42, 54-62.

Liu, Y., Wei, Z. \& Xie, F. 2013. Do women directors improve firm value in China? Journal of Corporate Finance, 46: 1-16.

López-Iturriaga, F. J., García-Meca, E. \& Tejerina Gaite, F. 2015. Institutional directors and board compensation: Spanish evidence. Business Research Quarterly, 18, 161-173.

Loukil, N. \& Yousfi, O. 2013. Does Gender Diversity on board lead to Risk-Taking? Empirical Evidence from Tunisia. Empirical Evidence from Tunisia (December 24, 2013).

Lückerath-Rovers, M. 2013. Women on boards and firm value. Journal of Management \& Governance, 17(2): 491-509.

Mak, Y. T. \& Kusnadi, Y. 2005. Size really matters: Further evidence on the negative relationship between board size and firm value. Pacific-Basin Finance Journal, 13(3): 301-318.

Manzaneque, M., Merino, E. \& Priego, A.M. 2016. The role of institutional shareholders as owners and directors and the financial distress likelihood. Evidence from a concentrated ownership context. European Management Journal, Forthcoming.

Martín-Ugedo, J. F. \& Mínguez-Vera, A. 2014. Firm value and Women on the Board: Evidence from Spanish Small and Medium-Sized Enterprises. Feminist Economics, (ahead-of-print), 1-27.

Masulis, R. W. \& Mobbs, S. 2011. Are all inside directors the same? Evidence from the external directorship market. Journal of Finance, 66(3): 823-872.

Mateos de Cabo, R. M., Gimeno, R. \& Escot, L. 2010. Discriminación en consejos de administración: Análisis e implicaciones económicas. Revista de Economía Aplicada, 18(53): $131-162$

Maznevski, M. L. 1994. Understanding our differences: Performance in decision-making groups with diverse members. Human relations, 47(5): 531-552.

McConnell, J.J. \& Servaes, H. 1990. Additional evidence on equity ownership and corporate value. Journal of Financial Economics, 27, 595-612. 
Morck, R., Shleifer, A. \& Vishny, R. W. 1988. Management ownership and market valuation: An empirical analysis. Journal of Financial Economics, 20: 293-315.

Muller-Kahle, M. I. 2012. The impact of dominant ownership: the case of Anglo-American firms. Journal of Management \& Governance, 1-19.

Navissi, F. \& Naiker, V. 2006. Institutional ownership and corporate value. Managerial Finance, 32(3): $247-56$.

Nekhili, M. \& Gatfaoui, H. 2013. Are Demographic Attributes and Firm Characteristics Drivers of Gender Diversity? Investigating Women's Positions on French Boards of Directors. Journal of Business Ethics, 118(2): 227-249

Neter, J., Wasserman, W. \& Kumer, M. 1985. Applied Linear Statistical Models. Irwin Press, Homewood, lL.

Nielsen, S. \& Huse, M. 2010. The contribution of women on Boards of Directors: Going beyond the Surface. Corporate Governance: An International Review, 18(2): 136-148.

Olivencia Report. 1998. El Buen Gobierno de las Sociedades. Madrid: Ministerio de Economía y Hacienda, Madrid.

Pathan, S. \& Faff, R. 2013. Does board structure in banks really affect their performance? Journal of Banking \& Finance, 37(5): 1573-1589.

Pelled, L. H. 1996. Demographic diversity, conflict, and work group outcomes: An intervention process theory. Organization Science, 7: 615-631.

Peng, M. W. 2004. Outside directors and firm value during institutional transitions. Strategic Management Journal, 25(5): 453-471.

Peng, M. W., Zhang, S. \& Li, X. 2007. CEO duality and firm value during China's institutional transitions. Management and Organization Review, 3(2): 205-225.

Pound, J. 1988. Proxy contest and the efficiency of shareholder oversight. Journal of Financial Economics, 20, 237-65.

Pucheta-Martínez, M. C. \& García-Meca, E. 2014. Institutional Investors on Boards and Audit Committees and Their Effects on Financial Reporting Quality. Corporate Governance: An International Review, 22(4): 347-363. 
Qi, B. \& Tian, G. 2012. The impact of Audit Committees' personal characteristics on earnings management: Evidence from China. Journal of Applied Business Research, 28(6): 1331-1343.

Rajgopal, S. \& Venkatachalam, M. 1998. The role of institutional investors in corporate governance: An empirical investigation. Working paper, University of Washington/Stanford University.

Rashid, A. 2012. Corporate governance, ownership structure and firm value: Evidence from an emerging economy. Corporate Ownership and Control, 9(4): 441-455.

Rashid, A. 2013. CEO duality and agency cost: evidence from Bangladesh. Journal of Management \& Governance, 17: 989-1008.

Rashid, A., De Zoysa, A., Lodh, S., \& Rudkin, K. (2010). Board composition and firm performance: Evidence from Bangladesh. Australasian Accounting, Business and Finance Journal, 4(1): $76-95$.

Robinson, G. \& Dechant, K. 1997. Building a Business Case for Diversity. Academy of Management Executive, 11(3): 21-30.

Rogelberg, S. G. \& Rumery, S. M. 1996. Gender diversity, team decision quality, time on task, and interpersonal cohesion. Small Group Research, 27(1): 79-90.

Ruegger, D. \& King, E. W. 1992. A study of the effect of age and gender upon student business ethics. Journal of Business Ethics, 11(3): 179-86.

Ruiz-Mallorquí, M. V. \& Santana-Martín, D. J. 2011. Dominant institutional owners and firm value. Journal of Banking \& Finance, 35(1): 118-129.

Sacramento, M., Moreira, A. C. \& Vieira, E. F. S. 2013. Blockholders presence, identity and institutional context. Are they relevant for firm value? International Journal Business Governance and Ethics, 8(1); 18-49.

Sahu, A. K. 2014. Do Financial Institutions Affect Firm Value? An Empirical Analysis in Indian Market. An Empirical Analysis in Indian Market (March 23, 2014).

Sahut, J. M. \& Othmani-Gharbi, H. 2010. Institutional Investors' Typology and Firm value: The Case of French Firms. International Journal of Business, 15(1): 33-50. 
Saunders, A., Cornett, M. M., Marcus, A. J. \& Tehranian, H. 2003. The Impact of Institutional Ownership on Corporate Operating Performance. NYU Stern Finance Working Paper No. 03033.

Schwartz-Ziv, M. 2011. Are all welcome a-board: What do women directors bring to the table. Working Paper, Hebrew University.

Sheikh, N. A., Wang, Z. \& Khan, S. 2013. The impact of internal attributes of corporate governance on firm value: Evidence from Pakistan. International Journal of Commerce and Management, 23(1): 38-55.

Shleifer, A. \& Vishny, R.W. 1986. Large shareholders and Corporate control. Journal of Political Economy, 94(3): 458-461.

Short, H. Zhang, H. \& Keasey, K. 2002. The link between dividend policy and institutional ownership. Journal of Corporate Finance, 8(2): 105-122.

Simons, T., \& Pelled, L. H. 1999. Understanding executive diversity: More than meets the eye. Human Resource Planning, 22, 49-51.

Singh, V. 2007. Ethnic diversity on top corporate boards: a resource dependency perspective. The International Journal of Human Resource Management, 18(12): 2128-2146.

Tajfel, H. 1978. Social categorization, social identity and social comparison. In H. Tajfel (Ed.), Differentiation between social groups: Studies in the social psychology of intergroup relations (pp. 61-76). London: Academic Press

Talpsepp, T. 2013. Does Gender and Age Affect Investor Performance and the Disposition Effect? Research in Economics and Business: Central and Eastern Europe, 2(1): 76-93.

Terjesen, S., Sealy, R. \& Singh, V. 2009. Women directors on corporate boards: A review and research agenda. Corporate Governance: An International Review, 17(3): 320-337.

Tian, J. J. \& Lau, C. M. 2001. Board composition, leadership structure and performance in Chinese shareholding companies. Asia Pacific Journal of Management, 18(2): 245-263.

Unified Code of Corporate Governance (CUBG). 2015. Informe del grupo especial de trabajo sobre buen gobierno de las sociedades cotizadas, Comité Conthe. Madrid. 
Valsan, R. 2015. Gender diversity in the boards of directors: A corporate governance perspective. Working paper, European Union Centre of Excellence, University of Alberta, Canada.

Van Essen, M., Van Oosterhout, J. \& Heugens, P. P. 2013. Competition and cooperation in corporate governance: The effects of labour institutions on blockholder effectiveness in 23 European countries. Organization Science, 24(2): 530-551.

Van Nuys, K., 1993. Corporate governance through the proxy process: Evidence from the 1989 Honeywell proxy solicitation. Journal of Financial Economics, 34: 101-132.

Van Pelt, T. 2013. The effect of board characteristics on dividend policy. Tilburg University, 1-62.

Villalonga, B. \& Amit, R. 2006. How do family ownership, control and management affect firm value? Journal of Financial Economics, 80(2): 385-417.

Vo, D. H. \& Nguyen, T. M. 2014. The Impact of Corporate Governance on Firm value: Empirical Study in Vietnam. International Journal of Economics and Finance, 6(6): 1-13.

Wahba, H. \& Elsayed, K. 2014. The effect of institutional investor type on the relationship between CEO duality and financial performance. International Journal of Business Governance and Ethics, 9(3): 221-242.

Wang, M. 2014. Which Types of Institutional Investors Constrain Abnormal Accruals? Corporate Governance: An International Review, 22(1): 43-67.

Wei, Z., Xie, F. \& Zhang, S. 2005. Ownership structure and firm value in China's privatized firms: 1991-2001. Journal of Financial and Quantitative Analysis, 40(01): 87-108.

Welch, S. \& Wang, Y. 2013. Is Manager Gender Important in the Performance of Mutual Funds? Accounting and Finance Faculty Publications, 6:1-31. Available: http://digitalcommons.csbsju.edu/acct_pubs/6

Wellalage, N., Fauzi, F. \& Wang, G. 2012. Corporate governance and cash dividend policy: Evidence from Chinese IPOs. Working Paper.

Yeh, Y. 2005. Do controlling shareholders enhance corporate value? Corporate Governance: An International Review, 13(2): 313-25.

Yuan, R., Xiao, J. Z. \& Zou, H. 2008. Mutual funds' ownership and firm value: Evidence from China. Journal of Banking \& Finance, 32(8): 1552-1565. 
Yermack, D. 1996. Higher valuation of companies with a small board of directors. Journal of Financial Economics, 40(2): 185-213.

Zou, H. 2010. Hedging affecting firm value via financing and investment: evidence from property insurance use. Financial Management, 39(3): 965-996. 
TABLE 1

Variable Definition

\begin{tabular}{|c|c|}
\hline Variables & Description \\
\hline Q_TOBIN & The market value of common stock plus book debt divided by total assets \\
\hline INST_WOM_BD & Proportion of institutional female directors on boards \\
\hline \multicolumn{2}{|c|}{$\begin{array}{c}\text { RESIST_WOM_BDProportion of the board female directors who are representative of pressure-resistant } \\
\text { institutional investors }\end{array}$} \\
\hline INST & Proportion of institutional directors on boards \\
\hline INDP_BD & Proportion of independent directors on boards \\
\hline CEO_DUALITY & $\begin{array}{l}\text { Dummy variable equals to } 1 \text { if the same person serves simultaneously as CEO and President } \\
\text { of the BD and } 0 \text {, otherwise }\end{array}$ \\
\hline OWNCON & The ownership concentration of the company \\
\hline INSOWN & Proportion of stocks held by directors \\
\hline LEV & Ratio of book debt to total assets \\
\hline ROA & Operate income before interests and taxes over total assets \\
\hline SIZE & The logarithm of the total assets (in thousands of Euros) \\
\hline BDSIZE & The total number of directors on boards \\
\hline DCRI_LAW & $\begin{array}{l}\text { Dummy variable that takes the value } 1 \text { if the period goes from } 2008 \text { to } 2013 \text { (period for } \\
\text { crisis and the period after the implementation of the } 3 / 2007 \text { Act) and } 0 \text {, otherwise }\end{array}$ \\
\hline $\operatorname{SEC}(1)$ & $\begin{array}{l}\text { Dummy variable that takes the value of } 1 \text { if the company belongs to oil and energy sector } \\
\text { and } 0 \text {, otherwise }\end{array}$ \\
\hline $\operatorname{SEC}(2)$ & $\begin{array}{l}\text { Dummy variable that takes the value of } 1 \text { if the company belongs the commodities, industry, } \\
\text { and construction sector and } 0 \text {, otherwise }\end{array}$ \\
\hline $\operatorname{SEC}(3)$ & $\begin{array}{l}\text { Dummy variable that takes the value of } 1 \text { if the company belongs the consumer goods sector } \\
\text { and } 0 \text {, otherwise }\end{array}$ \\
\hline SEC(4) & $\begin{array}{l}\text { Dummy variable that takes the value of } 1 \text { if the company belongs the consumer services } \\
\text { sector and } 0 \text {, otherwise }\end{array}$ \\
\hline $\operatorname{SEC}(5)$ & $\begin{array}{l}\text { Dummy variable that takes the value of } 1 \text { if the company belongs the financial services and } \\
\text { property sector and } 0 \text {, otherwise }\end{array}$ \\
\hline SEC(6) & $\begin{array}{l}\text { Dummy variable that takes the value of } 1 \text { if the company belongs the technology and } \\
\text { telecommunications sector and } 0 \text {, otherwise }\end{array}$ \\
\hline
\end{tabular}


TABLE 2

Main Descriptive Statistics

Mean, median, standard deviation, and percentiles of the main variables. Panel A and B show the continuous and dummy variables, respectively. Q_TOBIN is the market value of common stock plus book debt divided by total assets; INST_WOM_BD is the proportion of institutional female directors on the board; RESIST_WOM_BD is the proportion of the board female directors who are representative of pressure-resistant institutional investors; INST is the proportion of institutional directors on the board; INDP_BD is the proportion of independent directors on the board; OWNCON is the ownership concentration of the firm; INSOWN is the proportion of stocks held by directors; LEV is the ratio of book debt to total assets; ROA is the operate income before interests and taxes over total assets; BDSIZE is the total number of directors on board; SIZE is the natural logarithm of the total assets; CEO_DUALITY equals to 1 if the same person serves simultaneously as CEO and President of the BD and 0, otherwise; DCRI_LAW is a dummy variable that takes the value 1 if the period goes from 2008 to 2013 (period for crisis and the period after the implementation of the 3/2007 Act) and 0, otherwise; SEC (i) is a dummy variable that takes the value of 1 if the company belongs to the sector in question and 0 , otherwise.

Panel A. Continuous variables

\begin{tabular}{lcccccc}
\hline \multicolumn{1}{c}{ Variables } & N & Mean & Std. Dev. & Perc. 10 & Perc. 50 & Perc. 90 \\
\hline Q_TOBIN & 989 & 2.18 & 1.86 & 0.87 & 1.57 & 4.11 \\
INST_WOM_BD & 989 & $3.82 \%$ & $6.96 \%$ & $0.00 \%$ & $0.00 \%$ & $12.50 \%$ \\
RESIST_WOM_BD & 989 & $3.37 \%$ & $6.62 \%$ & $0.00 \%$ & $0.00 \%$ & $11.11 \%$ \\
INST & 989 & $43.41 \%$ & $23.16 \%$ & $12.50 \%$ & $44.44 \%$ & $75.00 \%$ \\
INDP_BD & 989 & $32.30 \%$ & $17.80 \%$ & $10.00 \%$ & $31.60 \%$ & $57.10 \%$ \\
OWNCON & 989 & $41.60 \%$ & $28.30 \%$ & $5.00 \%$ & $39.98 \%$ & $80.00 \%$ \\
INSOWN & 989 & $26.86 \%$ & $26.64 \%$ & $0.03 \%$ & $18.79 \%$ & $64.64 \%$ \\
LEV & 989 & $57.90 \%$ & $37.60 \%$ & $18.60 \%$ & $57.40 \%$ & $86.60 \%$ \\
ROA & 989 & $1.00 \%$ & $14.13 \%$ & $-11.00 \%$ & $2.60 \%$ & $15.90 \%$ \\
BDSIZE & 989 & 10.83 & 3.74 & 6.00 & 10.00 & 16.00 \\
SIZE & 989 & 13.30 & 1.84 & 11.01 & 13.16 & 15.74 \\
\hline
\end{tabular}

Panel B. Dummies variables

\begin{tabular}{lcccc}
\hline & $\mathbf{0}$ & $\mathbf{\%}(\mathbf{0})$ & $\mathbf{1}$ & $\mathbf{\%}(\mathbf{1})$ \\
\hline CEO_DUALITY & 633 & $64 \%$ & 356 & $36 \%$ \\
DCRI_LAW & 336 & $34 \%$ & 653 & $66 \%$ \\
SEC(1) & 891 & $90 \%$ & 98 & $10 \%$ \\
SEC(2) & 712 & $72 \%$ & 277 & $28 \%$ \\
SEC(3) & 712 & $72 \%$ & 277 & $28 \%$ \\
SEC(4) & 851 & $86 \%$ & 138 & $14 \%$ \\
SEC(5) & 841 & $85 \%$ & 148 & $15 \%$ \\
SEC(6) & 940 & $95 \%$ & 49 & $5 \%$ \\
\hline
\end{tabular}


TABLE 3

\section{Correlation Matrix}

Q TOBIN is the market value of common stock plus book debt divided by total assets; INST WOM BD is the proportion of institutional female directors on the board; RESIST WOM BD is the proportion of the board female directors who are representative of pressure-resistant institutional investors; INST is the proportion of institutional directors on the board; INDP_BD is the proportion of independent directors on the board; OWNCON is the ownership concentration of the firm; INSOWN is the proportion of stocks held by directors; LEV is the ratio of book debt to total assets; ROA is the operate income before interests and taxes over total assets; BDSIZE is the total number of directors on board; SIZE is the natural logarithm of the total assets; CEO_DUALITY equals to 1 if the same person serves simultaneously as CEO and President of the BD and 0, otherwise; DCRI_LAW is a dummy variable that takes the value 1 if the period goes from 2008 to 2013 (period for crisis and the period after the implementation of the 3/2007 Act) and 0, otherwise; SEC (i) is a dummy variable that takes the value of 1 if the company belongs to the sector in question and 0 , otherwise. ${ }^{* *}$ Significant at $1 \%, * *$ at $5 \%$ and $*$ at $10 \%$.

\begin{tabular}{|c|c|c|c|c|c|c|c|c|c|c|c|c|c|c|c|c|c|c|}
\hline & Q_TOBIN & $\begin{array}{c}{ }_{\text {INST_WOM_L }} \\
\overline{B D}\end{array}$ & $\begin{array}{c}\text { RESIST_WOM_ } \\
\text { BD }\end{array}$ & BDSIZE & OWNCON & INSOWN & LEV & $\mathrm{ROA}$ & SIZE & INST & $\begin{array}{l}\text { INDEP }_{-} \\
\mathrm{BD}_{-}\end{array}$ & $\begin{array}{c}\text { CEO } \\
\text { DUALITY }\end{array}$ & $\begin{array}{c}\text { DCRI_L } \\
\text { AW }\end{array}$ & $\operatorname{SEC}(1)$ & $\operatorname{SEC}(2)$ & $\operatorname{SEC}(3)$ & $\operatorname{SEC}(4)$ & $\operatorname{SEC}(5)$ \\
\hline $\begin{array}{l}\text { INST_WOM_ } \\
\text { BD }\end{array}$ & $-0.061^{*}$ & & & & & & & & & & & & & & & & & \\
\hline $\begin{array}{l}\text { RESIT_WOM } \\
\text { _BD }\end{array}$ & -0.004 & $0.925 * * *$ & & & & & & & & & & & & & & & & \\
\hline BDSIZE & $-0.055^{*}$ & 0.035 & 0.037 & & & & & & & & & & & & & & & \\
\hline OWNCON & $-0.084 * * *$ & $0.120^{* * *}$ & $0.123 * * *$ & $-0.077^{* *}$ & & & & & & & & & & & & & & \\
\hline INSOWN & $-0.063^{* *}$ & $0.260^{* * * *}$ & $0.204 * * *$ & $-0.176^{* * * *}$ & $0.287 * * *$ & & & & & & & & & & & & & \\
\hline LEV & $-0.135 * * *$ & $0.071^{* *}$ & $0.082^{* * *}$ & 0.049 & $0.149 * * *$ & $0.152 * * *$ & & & & & & & & & & & & \\
\hline ROA & $0.507 * * *$ & -0.050 & -0.006 & $0.194 * * *$ & -0.035 & $-0.144 * * *$ & $-0.285^{* * *}$ & & & & & & & & & & & \\
\hline SIZE & $-0.119^{* * * *}$ & -0.012 & 0.009 & $0.667 * * *$ & $0.117^{* * *}$ & $-0.259 * * *$ & $0.264 * * *$ & $0.125 * * *$ & & & & & & & & & & \\
\hline INST & $-0.109^{* * *}$ & $0.275^{* * *}$ & $0.221 * * *$ & $0.299 * * *$ & $0.170^{* * *}$ & $0.091^{* * *}$ & $0.091 * * *$ & -0.022 & $0.084^{* * * *}$ & & & & & & & & & \\
\hline INDP_BD & $0.056^{*}$ & $-0.273 * * *$ & $-0.208 * * *$ & $-0.080^{* *}$ & $-0.244 * * *$ & $-0.265^{* * *}$ & $-0.158^{* * *}$ & 0.037 & $0.076^{* *}$ & $-0.639 * * *$ & & & & & & & & \\
\hline $\begin{array}{l}\text { CEO_DUALI } \\
\text { TY }\end{array}$ & -0.045 & -0.047 & -0.036 & $-0.092 * * *$ & -0.033 & $0.097^{* * *}$ & -0.015 & 0.014 & -0.029 & $-0.272 * * *$ & $0.122 * * *$ & & & & & & & \\
\hline DCRI_LAW & $-0.363^{* * *}$ & $0.079^{* *}$ & 0.049 & $-0.060^{*}$ & $0.069^{* *}$ & $0.054 *$ & $0.087^{* * *}$ & $-0.203^{* * *}$ & 0.027 & -0.007 & 0.040 & 0.028 & & & & & & \\
\hline $\mathrm{SEC}(1)$ & $-0.066^{* *}$ & $-0.077^{* *}$ & $-0.057^{*}$ & $0.183^{* * * *}$ & $-0.059^{*}$ & $-0.273 * * *$ & $-0.141 * * *$ & $0.069^{* *}$ & $0.288^{* * * *}$ & -0.036 & $0.199 * * *$ & -0.015 & -0.027 & & & & & \\
\hline $\operatorname{SEC}(2)$ & -0.012 & $0.118^{* * *}$ & $0.143 * * *$ & 0.049 & 0.025 & 0.051 & $0.182 * * *$ & -0.016 & 0.038 & $0.131^{* * *}$ & $-0.096^{* * * *}$ & $0.087 * * *$ & -0.023 & $-0.197 * * *$ & & & & \\
\hline $\operatorname{SEC}(3)$ & $0.088^{*}$ & -0.013 & -0.017 & $-0.286^{* * *}$ & $-0.220 * * *$ & $0.103^{* * *}$ & $-0.235 * * *$ & $0.087 * * *$ & $-0.291 * * *$ & $-0.082^{* *}$ & -0.024 & $-0.074^{* *}$ & -0.017 & $-0.198 * * *$ & $-0.394 * * *$ & & & \\
\hline $\operatorname{SEC}(4)$ & -0.022 & $0.080^{* *}$ & 0.035 & $0.122 * * *$ & $0.139 * * *$ & $0.067^{* *}$ & $0.109^{* * * *}$ & -0.004 & $0.064 * *$ & 0.027 & -0.031 & -0.000 & 0.000 & $-0.129 * * *$ & $-0.257^{* * *}$ & $-0.257^{* * *}$ & & \\
\hline $\operatorname{SEC}(5)$ & -0.022 & $-0.081 * *$ & $-0.088^{*}$ & 0.026 & $0.287 * * *$ & 0.011 & 0.036 & $-0.116^{* * *}$ & -0.005 & 0.019 & $-0.112^{* * * *}$ & 0.045 & 0.067 & $-0.132 * * *$ & $-0.263 * * *$ & $-0.264 * * *$ & $-0.172 * * *$ & \\
\hline $\operatorname{SEC}(6)$ & 0.003 & $-0.108^{* * *}$ & $-0.096^{* * *}$ & $0.094^{* * * *}$ & $-0.208^{* * *}$ & $-0.085^{* * *}$ & $0.060^{*}$ & -0.042 & 0.048 & $-0.128^{* * *}$ & $0.215^{* * * *}$ & $-0.079^{* *}$ & 0.009 & $-0.073^{* *}$ & $-0.146 * * *$ & $-0.146^{* * * *}$ & $-0.095^{* * *}$ & $-0.097^{* * * *}$ \\
\hline
\end{tabular}


TABLE 4

Test of Means Comparison

Q_TOBIN is the market value of common stock plus book debt divided by total assets; INST_WOM_BD is the proportion of institutional female directors on the board; RESIST_WOM_BD is the proportion of the board female directors who are representative of pressure-resistant institutional investors; p-value is the significance level to accept the null hypothesis of equality of means between groups.

\begin{tabular}{lcccc}
\hline Variable & $\begin{array}{c}\text { Q_TOBIN }(>=1,57) \\
\text { Mean }\end{array}$ & $\begin{array}{c}\text { Q_TOBIN }(<1,57) \\
\text { Mean }\end{array}$ & $\begin{array}{c}\text { Mean } \\
\text { difference }\end{array}$ & p-value \\
\hline INST_WOM_BD & 4.401 & 3.253 & 1.148 & 0.009 \\
RESIST_WOM_BD & 3.672 & 3.065 & 0.607 & 0.000 \\
\hline
\end{tabular}


TABLE 5

Results of the lineal and logarithmic regression for institutional and pressure-resistant female directors sit on the board of directors

Estimated coefficients (p-value). Q_TOBIN is the market value of common stock plus book debt divided by total assets; INST_WOM_BD is the proportion of institutional female directors on the board if the lineal model is used or the logarithm of the proportion of institutional female directors on the board it the logarithmic model is used; RESIST WOM BD is the proportion of the board female directors who are representative of pressure-resistant institutional investors if the lineal model is used and the logarithm of the board female directors who are representative of pressure-resistant institutional investors if the logarithmic model is used; INST is the proportion of institutional directors on the board; INDP_BD is the proportion of independent directors on the board; OWNCON is the ownership concentration of the firm; INSOWN is the proportion of stocks held by directors; LEV is the ratio of book debt to total assets; ROA is the operate income before interests and taxes over total assets; BDSIZE is the total number of directors on board; SIZE is the natural logarithm of the total assets; CEO_DUALITY equals to 1 if the same person serves simultaneously as CEO and President of the BD and 0, otherwise; DCRI_LAW is a dummy variable that takes the value 1 if the period goes from 2008 to 2013 (period for crisis and the period after the implementation of the 3/2007 Act) and 0, otherwise; SEC (i) is a dummy variable that takes the value of 1 if the company belongs to the sector in question and 0 , otherwise. ${ }^{* * *}$ Significant at $1 \%, * *$ at $5 \%$ and $*$ at $10 \%$.

\begin{tabular}{|c|c|c|c|}
\hline & $\begin{array}{l}\text { Expected } \\
\text { sign }\end{array}$ & $\begin{array}{c}\text { Model 1 } \\
\text { coefficient } \\
\text { (p-value) }\end{array}$ & $\begin{array}{c}\text { Model } 2 \\
\text { coefficient } \\
\text { (p-value) }\end{array}$ \\
\hline INST_WOM_BD & + & $\begin{array}{l}0.028^{*} \\
(0.095)\end{array}$ & \\
\hline INST_WOM_BD ${ }^{2}$ & - & $\begin{array}{l}-0.001^{*} \\
(0.078)\end{array}$ & \\
\hline RESIST_WOM_BD & + & & $\begin{array}{l}0.044 * * \\
(0.034)\end{array}$ \\
\hline RESIST_WOM_BD ${ }^{2}$ & - & & $\begin{array}{c}-0.002^{* *} \\
(0.014)\end{array}$ \\
\hline INST & $+/-$ & $\begin{array}{c}0.005 \\
(0.106)\end{array}$ & $\begin{array}{c}0.005 \\
(0.118)\end{array}$ \\
\hline INDP_BD & + & $\begin{array}{c}0.012 * * * \\
(0.002)\end{array}$ & $\begin{array}{c}0.012 * * * \\
(0.001)\end{array}$ \\
\hline CEO_DUALITY & $+/-$ & $\begin{array}{c}0.000 \\
(0.830)\end{array}$ & $\begin{array}{c}0.000 \\
(0.796)\end{array}$ \\
\hline OWNCON & + & $\begin{array}{l}-0.000 \\
(0.933)\end{array}$ & $\begin{array}{l}-0.000 \\
(0.895)\end{array}$ \\
\hline INSOWN & + & $\begin{array}{l}-0.003 \\
(0.181)\end{array}$ & $\begin{array}{l}-0.003 \\
(0.181)\end{array}$ \\
\hline LEV & + & $\begin{array}{c}0.001 \\
(0.573)\end{array}$ & $\begin{array}{c}0.001 \\
(0.607)\end{array}$ \\
\hline ROA & + & $\begin{array}{c}0.001 \\
(0.838)\end{array}$ & $\begin{array}{c}0.001 \\
(0.846)\end{array}$ \\
\hline BDSIZE & - & $\begin{array}{c}-0.065 * * * \\
(0.001)\end{array}$ & $\begin{array}{c}-0.066^{* * * *} \\
(0.001)\end{array}$ \\
\hline SIZE & + & $\begin{array}{c}0.137 * * * \\
(0.000)\end{array}$ & $\begin{array}{c}0.137 * * * \\
(0.000)\end{array}$ \\
\hline DCRI_LAW & $+/-$ & $\begin{array}{c}-0.012 * * * \\
(0.000)\end{array}$ & $\begin{array}{c}-0.011 * * * \\
(0.000)\end{array}$ \\
\hline $\operatorname{SEC}(2)$ & + & $\begin{array}{c}0.012 * * * \\
(0.000)\end{array}$ & $\begin{array}{c}0.012 * * * \\
(0.000)\end{array}$ \\
\hline $\operatorname{SEC}(3)$ & + & $\begin{array}{c}0.013 * * * \\
(0.000)\end{array}$ & $\begin{array}{c}0.013^{* * *} * \\
(0.000)\end{array}$ \\
\hline $\operatorname{SEC}(4)$ & + & $\begin{array}{c}0.012^{* * * *} \\
(0.000)\end{array}$ & $\begin{array}{c}0.012 * * * \\
(0.000)\end{array}$ \\
\hline $\operatorname{SEC}(5)$ & + & $\begin{array}{c}0.016^{* * *} \\
(0.000)\end{array}$ & $\begin{array}{c}0.016^{* * * *} \\
(0.000)\end{array}$ \\
\hline $\operatorname{SEC}(6)$ & + & $\begin{array}{c}0.011 * * * \\
(0.001)\end{array}$ & $\begin{array}{c}0.011^{* * *} * \\
(0.000)\end{array}$ \\
\hline $\begin{array}{l}\mathrm{F} \\
\mathrm{R}^{2}\end{array}$ & & $\begin{array}{c}88.03 * * * \\
61.87 \%\end{array}$ & $\begin{array}{c}89.89 * * * \\
61.96 \%\end{array}$ \\
\hline
\end{tabular}

